\title{
Factors affecting the spread of parasites in populations of wild European terrestrial mammals
}

\author{
Marta Kołodziej-Sobocińska ${ }^{1}$ (D)
}

Received: 17 August 2018 / Accepted: 21 February 2019 /Published online: 7 March 2019

(C) The Author(s) 2019

\begin{abstract}
There are many different factors involved in parasitism. The general concept of "filters" proposed by Combes includes "encounter filters" (behavior, biodiversity) and "compatibility filters" (resources, defense) to explain mechanisms responsible for the formation of host-parasite coexistence. However, researches explaining the reasons for the spread and dynamics of parasites in populations of wild terrestrial mammals in Europe and the specific factors affecting prevalence and intensity of parasitosis are limited. Many factors, ecological, biological, and anthropogenic, form a complex network of interdependencies that shape this pattern. Here, I summarize the current state of knowledge on the factors affecting parasitic diseases in wild mammals inhabiting the European continent. It indicates the need to further development, not only for academic reasons, but also for the benefit of use in management of wild mammal species and disease control in nature.
\end{abstract}

Keywords Parasites $\cdot$ Wildlife $\cdot$ Mammals $\cdot$ Transmission $\cdot$ Zoonoses

\section{Introduction}

Parasite dynamics can be strongly affected by numerous (biological, ecological, and anthropogenic) factors. Combes (1991, 2001) proposed the concept of "filters" to describe the mechanisms responsible for formation of host-parasite coexistence. They are "encounter filters," which determine the probability of contact between the parasite and potential host (e.g., behavior, biodiversity) and "compatibility filters," which delimit the probability of the parasite and potential host living together (e.g., resource, defense). Combes' concepts of encounter and compatibility as a sequence of filters allow a more complete understanding of the parasite-host relationship (Combes 2001); however, in this concept, there is no consideration of anthropogenic factors which also may play a very important role in host-parasite coexistence formation (e.g., Cunningham 1996; Murray et al. 2016; Vadlejch et al. 2016). Specific factors influencing host-parasite associations are, among others, climate conditions, behavioral traits, host

Communicated by: Justin G. Boyles

Marta Kołodziej-Sobocińska

mksobocinska@ibs.bialowieza.pl

1 Mammal Research Institute, Polish Academy of Sciences, Stoczek 1, 17-230 Białowieża, Poland sociality, population density, diet, habitat, age, sex, host immunocompetence, supplementary feeding, and animal translocations (e.g., Cornell et al. 2008; Kołodziej-Sobocińska et al. 2014b, 2016a, 2018b; Solomon et al. 2015; Woolhouse 1998; Zuk and McKean 1996).

Parasitic infections that are present in wildlife may have important effects on individuals and populations (Møller 2005), which could be an especially critical issue in conservation of threatened species (Thompson et al. 2010). Parasites may cause deleterious effects on their hosts (Anderson and May 1979; Prado et al. 2009), and so both the host and parasite are forced to constantly adapt to one another (SchmidHempel 2011). This sometimes leads to a relatively stable relationship tending toward a parasite-host balance, as it is in the evolutionary interest of the parasite that its host survives (Rook 2007). Moreover, infected wild terrestrial mammals could have an important influence on human health, as they are reservoirs for many zoonotic diseases including echinococossis (Echinococcus spp.), toxocarosis (Toxocara spp.), trichinellosis (Trichinella spp.), toxoplasmosis (Toxoplasma spp.), alariosis (Alaria spp.), and many others (Antolova et al. 2009, 2014; Duscher et al. 2017; Hurníková et al. 2016; Kern et al. 2003; Krucken et al. 2017; Lassen et al. 2016; Machnicka-Rowińska et al. 2002; Nahorski et al. 2013; Oksanen et al. 2016; Poeppl et al. 2013; Suld et al. 2014; Sutor et al. 2014; Thompson 2013; Thompson et al. 2010). 
The complex processes and factors shaping the dynamics of parasitic diseases prompted me to review the current state of knowledge on this topic. I focus on parasites in populations of wild terrestrial mammals inhabiting the European continent because there is a particularly strong body of available research papers for European terrestrial mammals and their parasites; however, I noticed the lack of comprehensive literature review on factors affecting parasitosis in European wildlife. It can be assumed that comprehensive studies are only feasible through the combination of parasitological data with knowledge about the ecology and biology of mammalian hosts, their responses to infection, the history and range of non-native invasive species, or the methods of species management.

\section{Difficulties in parasitological studies of mammals in the wild}

One of the main problems concerning characterization and systematization of wild mammals' parasitofauna is the diversification of mammalian hosts. Further, for many species, it is difficult or even impossible to collect research material because of their protection status or rarity. In addition, there is scarce information on parasites and parasite gene sequences. Many studies on parasitic diseases of wild mammals involve determining the parasite species composition of particular wild hosts (Bień et al. 2010; Demiaszkiewicz et al. 2013; Dróżdż et al. 1998; Reiterová et al. 2006). Due to the limited availability of wild animal carcasses, especially of protected species, studies often rely on detection of parasite eggs in mammal feces (Górski et al. 2006; Szczęsna et al. 2008; Turgeon et al. 2018). This method, however, has limitations, including the seasonality of parasite egg shedding and difficulty in their proper identification (Hines et al. 2007; Pyziel et al. 2011). Molecular methods for species identification are necessary to obtain reliable and accurate results (Haukisalmi et al. 2018; Kołodziej-Sobocińska et al. 2018c; Vichova et al. 2011; Walker et al. 2013) and these techniques should be further developed and implemented. Specifically, for many parasite species of mammals, there is a lack of reliable data entries to open-source repositories.

More generally, several difficulties arise in parasitological studies of wild mammals. First, advances in the methodology of parasite isolation and identification make comparisons of past and contemporary research difficult. In addition, inter-individual differences connected to coinfection with other pathogens (Viney and Graham 2013), food availability (Friesen et al. 2015), age (Woolhouse 1998), breeding status (Grear et al. 2009), etc., may significantly impede the interpretation of results and their comparison among wild animals of the same species from different populations, localizations, and habitats. Finally, rare and unique material from wild mammals is often used not only for parasitological studies but also for other types of studies (e.g., diet analyses), which can distort parasitological analyses because some species of parasites inhabit mainly host stomachs (Kołodziej-Sobocińska et al. 2018a). The necessity of comprehensive studies taking into account these limitations is indispensable for understanding parasitic infections in wild populations. Many of them are discussed in the presented review, which should facilitate the planning of parasitological research of wild animals.

\section{Factors affecting the spread of parasites in wildlife}

Potential factors determining the transmission of parasites include environmental conditions that affect the viability and behavior of parasites (Rogers and Sommerville 1963) and feeding, movement, and defecation patterns of the host, which determine the parasites encountered (Lozano 1991; Price et al. 1988; Watve and Sukumar 1995). In addition, parasite species diversity and infection intensity can have a wide range of impacts on hosts, in terms of their (1) health (Johnson and Hoverman 2012; Tompkins et al. 2011); (2) behavior (Herbison et al. 2018; Milinski 1984; Moore 1984); (3) sexual selection (Auld et al. 2016; Penn and Potts 1998; Watve and Sukumar 1995); and (4) regulation of host populations (Dobson 1988; Kołodziej-Sobocińska et al. 2018a; Lefevre et al. 2009; Tompkins et al. 2011). Encounter (biodiversity, behavior) and compatibility (resource, defense) filters responsible for shaping hostparasite associations may be closed and/or open (Combes 1991, 2001). Thus, there are four possible combinations: (1) both filters are closed - the host-parasite association cannot exist; (2) the encounter filter is opened, but the compatibility filter is closed - the parasite-host association does not exist, but selective pressure on the parasite may allow some individuals of the parasite (e.g., selected mutants) to open the compatibility filter; (3) the encounter filter is closed, but the compatibility filter is open - the parasite-host association also does not exist, although a change in composition of the ecosystem or in host behavior may open the filter and result in association; (4) both the encounter and compatibility filters are open and the host-parasite association may exist (Combes 2001).

Worldwide, mammals are so diverse that it is impossible to discuss their interdependences with parasite communities in one paper. Thus, I decided to focus on selected terrestrial mammals of Europe, which are the closest to my interest and relatively little explored in this context. The choice of literature on factors affecting the spread of parasites in populations of wild European terrestrial mammals has been summarized in Table 1. The following sections address some of 
Table 1 Review of factors affecting the spread of parasites in wild terrestrial mammals with examples of references

\begin{tabular}{ll} 
Type of factor & Factor name \\
\hline Ecological & $\begin{array}{r}\text { Population ecology, population status, } \\
\text { population density, population size }\end{array}$
\end{tabular}

Migration, colonization

Competition, predation

Climate, season

Food availability, diet

Behavior, sociality

Non-native invasive mammal species

Non-native invasive parasite species

Biological Sex, breeding status, sexual selection

Age

Body condition, health, immunocompetence

Anthropogenic Supplementary feeding

Introduction, reintroduction, translocation, conservation

Zoonotic diseases
References

Anderson (1982); Anderson and May (1978); Beldomenico et al. (2008); Hoberg and Brooks (2015); Holmala and Kauhala (2006); Hudson et al. (2006a, b); Kelly et al. (2009); Lefevre et al. (2009); Lindenfors et al. (2007); Møller (2005); Peacock et al. (2018); Pedersen and Fenton (2007); Scott (1988); Smith et al. (2009); Stringer and Linklater (2015); Sugiura et al. (2018); Telfer et al. (2008, 2010); Tompkins et al. (2011); Torres et al. (2006); Wang et al. (2016); Watve and Sukumar (1995); Winternitz et al. (2012)

Altizer et al. (2011); Anisimova (2004); Brown and Hall (2018); Dobson (1988); Folstad et al. (1991); Kołodziej-Sobocińska et al. (2018a); Lindenfors et al. (2007); Mysterud et al. (2016); Peacock et al. (2018); Teitelbaum et al. (2018); Torres et al. (2006)

Bohm et al. (2008); Bonsall and Hassell (1999); Kołodziej-Sobocińska et al. (2014b); Ostfeld and Holt (2004); Price et al. (1988); Raffel et al. (2010); Rohr et al. (2015); Telfer et al. (2010)

Altizer et al. (2006); Begon et al. (2009); Brooks et al. (2014); Cable et al. (2017); Cattadori et al. (2005); Cornell et al. (2008); Harvell et al. (2002); Hoberg and Brooks (2015); Holmes et al. (2018); Hudson et al. (2006a); Kołodziej-Sobocińska et al. (2016d); Kutz et al. (2014); Lafferty (2009); Martin et al. (2008); Mysterud et al. (2016); Pedersen and Fenton (2007); Pyziel et al. (2011); Studer et al. (2010); Turner and Getz (2010)

Bień et al. (2016); Brown and Hall (2018); Dróżdż et al. (2003); Duscher et al. (2017); Friesen et al. (2015); Górski et al. (2006); Hart and Hart (2018); Kołodziej-Sobocińska et al. (2016c, d, 2018c); Lozano (1991); Pyziel et al. (2011); Rohr et al. (2015); Turner and Getz (2010)

Bohm et al. (2008); Curtis (2014); Hart and Hart (2018); Herbison et al. (2018); Kavaliers and Choleris (2018); Kołodziej-Sobocińska et al. (2014b); Milinski (1984); Moore (1984); Sarabian et al. (2018); Weinstein et al. (2018a, 2018b)

Bonesi and Palazon (2007); Chaneton and Bonsall (2000); Colautti et al. (2004); Cybulska et al. (2018); Gendron et al. (2012); Hurníková et al. (2016); Keogh et al. (2017);

Kołodziej-Sobocińska et al. (2018a); Laurimaa et al. (2016); Lymbery et al. (2014); Poulin (2017); Prenter et al. (2004); Sherrard-Smith et al. (2015); Sugiura et al. (2018); Sutor et al. (2014); Torchin et al. (2003)

Daszak et al. (2000); Dróżdż et al. (1998); Garbarino et al. (2017); Kanchev et al. (2012); Kołodziej-Sobocińska et al. (2016a); Lymbery et al. (2014); Price et al. (1986); Romeo et al. (2015); Taraschewski (2006); Vadlejch et al. (2016)

Alexander and Stimson (1988); Auld et al. (2016); Folstad and Karter (1992); Friesen et al. (2015); Fuxjager et al. (2011); Grear et al. (2009); Kiffner et al. (2013); Klein (2004); Kołodziej-Sobocińska et al. (2016a, 2018a); Krishnan et al. (1996); Lloyd (1983); Penn and Potts (1998); Poulin (1996); Turner and Getz (2010); Watve and Sukumar (1995); Zuk and McKean (1996)

Bush et al. (2001); Cornell et al. (2008); Kethineni et al. (2006); Kołodziej-Sobocińska et al. (2016a, 2018a); Treboganova (2010); Turner and Getz (2010); Woolhouse (1998)

Beldomenico et al. (2008); Bize et al. (2008); Cornell et al. (2008); Davidson et al. (2015); Johnson and Hoverman (2012); Kołodziej-Sobocińska et al. (2014b, 2016b, 2018a); Lindenfors et al. (2007); Martin et al. (2003); Sánchez et al. (2018); Schulte-Hostedde and Elsasser (2011); Schulte-Hostedde et al. (2005); Stien et al. (2002); Tompkins et al. (2011); Turgeon et al. (2018); Wilder et al. (2016); Winternitz et al. (2012)

Kołodziej-Sobocińska et al. (2016a, d); Kozak et al. (1995); Loarie et al. (2009); Murray et al. (2016); Oja et al. (2017); Pyziel et al. (2011); Radwan et al. (2010); Sorensen et al. (2014); Suld et al. (2014)

Cunningham (1996); Daszak et al. (2000); Dickens et al. (2010); Dobson (1988); Faria et al. (2010); Karbowiak et al. (2014); Kołodziej-Sobocińska et al. (2018b, c); Mathews et al. (2006); Pedersen et al. (2007); Scott (1988); Stringer and Linklater (2015); Turgeon et al. (2018); Vadlejch et al. (2016); Viggers et al. (1993); Wakelin (1978)

Antolova et al. (2009, 2014); Bastien et al. (2018); Bień et al. (2016); Chen et al. (2018); Cybulska et al. (2018); Daszak et al. (2000); Duscher et al. (2017); Garbarino et al. (2017); Gazzonis et al. (2018); Górski et al. (2006); Hurníková et al. (2016); Karamon et al. (2014); Karssin et al. (2017); Kołodziej-Sobocińska and Miniuk (2018); Kołodziej-Sobocińska et al. (2016c, 2018c); Krucken et al. (2017); Laurimaa et al. (2016); Mackenstedt et al. (2015); Polley (2005); Rentería-Solís et al. (2018a, b); Schweiger et al. (2007); Serrano-Moliner et al. (2018); Sutor et al. (2014); Thompson (2013); Weinstein et al. (2018b) the most relevant aspects and examples in detail. I provide examples referring to European terrestrial mammals, but in some cases, lack of research illustrating adequately a given problem forced me to use examples of terrestrial mammals from other continents. To better illustrate the complexity of the reviewed topic, the network of host-parasite associations and factors influencing their coexistence are presented in Fig. 1. 


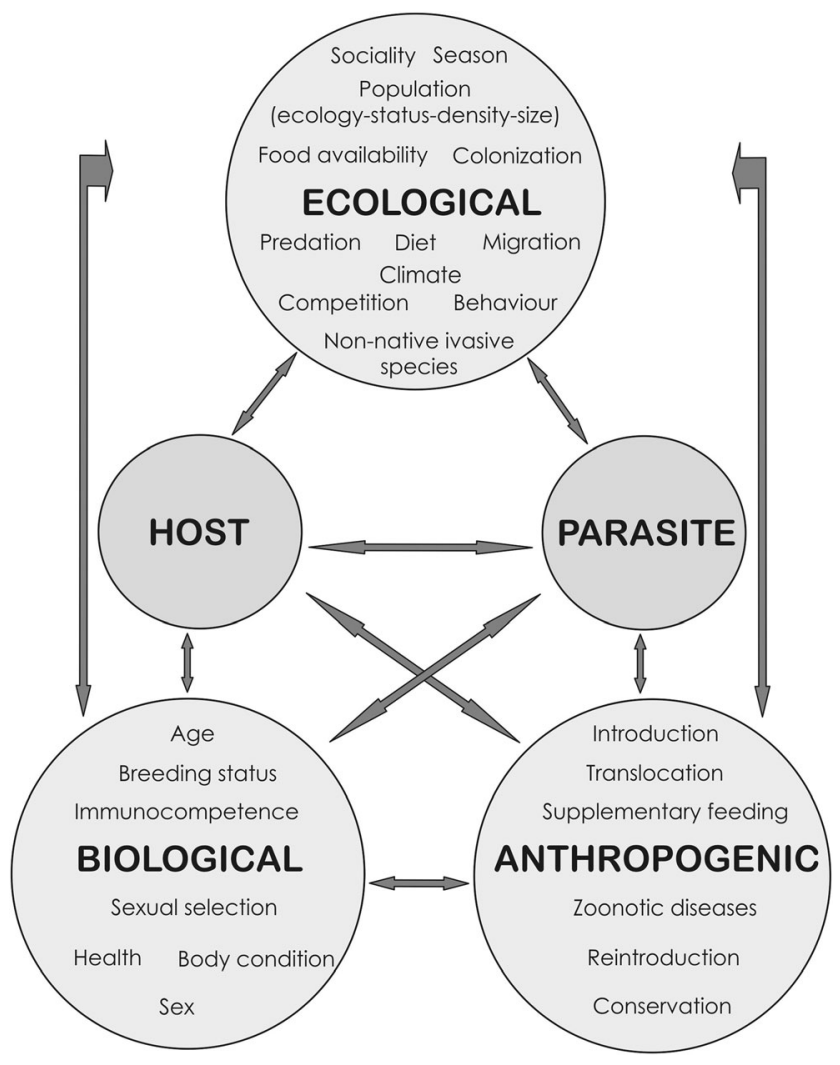

Fig. 1 The network of host-parasite associations with factors influencing their coexistence in wildlife

\section{Ecological factors}

\section{Population ecology, status, density, and size}

Host population size is important in the context of hostparasite interactions because the spread of parasites is able to persist only if the number of hosts is above critical threshold (Anderson and May 1979). Population size often depends on population health status; the size of the weakened population with higher mortality rates will be smaller, which should slow down pathogen transmission. On the other hand, such populations are more susceptible to infection, as lowered fitness, condition, and immune defense favor disease occurrence and spread. Also population density may strongly increase risk of disease transmission through close contact between mating pairs or group members (Sugiura et al. 2018). Contact rate between individuals may be also accelerated by host behavior and sociality. The pooled density of medium-sized carnivores showing high space use overlaps and increased potential contact rate may exceed the threshold density needed for disease spread (Holmala and Kauhala 2006). A novel approach is using contact networks to explore and understand the dynamics of disease transmission; for example, data on African lion (Panthera leo) behavior and movement provide sophisticated evidence that outbreaks of canine distemper virus are partly driven by interspecific interactions among lions, spotted hyenas (Crocuta crocuta), and jackals (Canis spp.) (Craft et al. 2008; Tompkins et al. 2011). All these interdependencies work bidirectionally as pathogens have an impact on animal populations, but population status, size, and density influence the speed and efficiency of disease transmission and spread (Scott 1988; Tompkins et al. 2011).

\section{Migration and colonization}

Host migration affects parasite dynamics in many wildlife species (Peacock et al. 2018). Spatiotemporal changes in host density due to migration patterns have profound and diverse consequences for parasite-host interactions (Altizer et al. 2011). For example, seasonal migrations of ungulates, such as red deer (Cervus elaphus), have an impact on parasite species diversity, load, and epidemiology (Mysterud et al. 2016). On the one hand, long-distance host migration enhances the spread of pathogens, including those of zoonotic potential, and facilitates cross-species transmission (Altizer et al. 2011); on the other, migratory hosts may escape parasitism. Such migratory escape has been proposed as a driver of postcalving migration in reindeer (Rangifer tarandus tarandus) in Norway (Folstad et al. 1991) and for non-native invasive American mink (Neovison vison) colonizing new territories in Poland (Kołodziej-Sobocińska et al. 2018a). Migratory demands can also reduce immune function, with consequences for host susceptibility and mortality (Altizer et al. 2011).

\section{Competition and predation}

Competition and predation can influence rates of parasite infection by altering population densities of hosts and vectors (Raffel et al. 2010). These traits increase the contact rate between individuals of the same or multiple species and therefore increase the likelihood of being infected. This pattern has been shown in studies of sarcoptic mange in carnivore communities inhabiting Białowieża Primeval Forest (BPF), Poland (Kołodziej-Sobocińska et al. 2014b). Intra-guild predation observed among wolves (Canis lupus) and lynxes (Lynx lynx) preying upon medium-sized carnivores like the red foxes (Vulpes vulpes) or raccoon dogs (Nyctereutes procyonoides) was one of the behavioral traits affecting sarcoptic mange occurrence (Kołodziej-Sobocińska et al. 2014b). Alternately, predators compete for and kill their prey; therefore, they consume both parasites and their hosts, and limit the number and density of infected individuals (Rohr et al. 2015). Lower host density may either decrease densitydependent transmission or increase per capita exposure, when the source of infection is at least temporarily independent of host density (Ostfeld and Holt 2004; Raffel et al. 2010). Additionally, predators often induce changes in behavioral traits of prey, which can modulate parasite transmission by 
altering the rate of encounter described as the Combes' encounter filter (Combes 2001; Raffel et al. 2010).

\section{Climate and season}

Host-parasite dynamics can be strongly affected by both climate and season (Altizer et al. 2006; Brooks et al. 2014; Cattadori et al. 2005; Cornell et al. 2008; Hudson et al. 2006a). Long dry seasons or very low temperatures limit development and survival of parasites in the environment and, as a result, host contact and parasite transmission. In addition, during the dry season, hosts shed far fewer parasite propagules into the environment than during the wet season (Holmes et al. 2018; Kutz et al. 2014; Turner and Getz 2010). Climate change affects hosts, vectors, parasites, vegetation, abiotic elements of the ecosystem, and many of the associations among these that affect the parasite web and parasite flow (Cable et al. 2017). Identification of all components of an ecosystem potentially susceptible to climate change is difficult, but perhaps easier than predicting the impacts of change. Among them, temperature, precipitation, and atmospheric $\mathrm{CO}_{2}$ have been studied, but interactions between them and consequent effects on parasite transmission are complex and very difficult to trace (Harvell et al. 2002). This is because these climate components may counteract each other, such that the overall rate of parasite transmission remains unchanged. For example, a higher temperature increases parasite growth and infectivity; however, if too high, it may also increase parasite mortality (Lafferty 2009; Studer et al. 2010).

\section{Food availability and diet}

Source of food is an important factor for parasite transmission, because predators and scavengers consume prey along with their parasites. Some prey may be a source of infection, such as when a predator or scavenger is a viable host for a particular parasite species, e.g., Trichinella spp., Toxocara spp., or Echinococcus spp. (Bień et al. 2016; Duscher et al. 2017; Górski et al. 2006; Kołodziej-Sobocińska et al. 2018c); this can cause disease spread and transmission. Otherwise, when the predator is not and cannot be a host (Combes' compatibility filters are closed), infection does not occur and the consumed parasite will die. This is the case for some gastrointestinal parasites of herbivorous mammals, where disease transmission occurs only through the excretion of eggs/oocysts in feces and contamination of the environment (Dróżdż et al. 2003; Kołodziej-Sobocińska et al. 2016a, d; Pyziel et al. 2011; Turner and Getz 2010). In this situation, predation is not the cause of spread; parasite transmission occurs because animals are more densely aggregated in a particular place due to human activity, such as supplementary feeding or utilization of the same pastures as livestock (Barger et al. 1994; Kołodziej-Sobocińska et al. 2016a, d). The seasonal availability of food is also an important aspect. One American mink study revealed significantly lower Aonchotheca putorii nematode abundance in the nonbreeding season (September-January) than in the breeding season (February-May) (Kołodziej-Sobocińska et al. 2018a). The increased abundance of this nematode in mink gastrointestinal tracts between February and May possibly resulted from the availability of earthworms, which are intermediate hosts for A. putorii. In Canada, infection intensity of A. putorii in the raccoon (Procyon lotor) was also the highest during spring and lowest during winter (Butterworth and Beverleyburton 1981).

\section{Behavior and sociality}

Wild animals are subject to strong selection from parasites and other infectious agents. This results in behavioral adaptations that help potential hosts avoid falling prey to parasites (Sarabian et al. 2018). This phenomenon is known as the "landscape of disgust" (Weinstein et al. 2018a) and is similar to the "landscape of fear" theory of predator avoidance in that parasite avoidance behavior can also affect ecology and evolution (Kuijper et al. 2013; Schmidt and Kuijper 2015; Weinstein et al. 2018a). Parasite and predator avoidance strategies sometimes have mutual effects, e.g., avoiding predator feces protects prey against both predators and their parasites (Weinstein et al. 2018b). In much the same way as predator avoidance, parasite avoidance has strong effects on foraging, movement, and social interactions (Curtis 2014). Several strategies have evolved that enable wild mammals to deal with parasites. These include eliminating infectious agents from sleeping/resting areas, having an array of grooming techniques, consuming medicinal plant-based compounds, and others (Hart and Hart 2018). These strategies are speciesspecific and reflect particular environments that animals inhabit. Sarcoptic mange is an example of a disease whose spread depends on host sociality and behavior. It is a highly contagious mite infection responsible for epizootic skin disease in populations of wild and domestic mammals worldwide (Arlian 1989; Pence and Ueckermann 2002; Sugiura et al. 2018). Social carnivores are more susceptible to mange than solitary ones (Kołodziej-Sobocińska et al. 2014b; Sugiura et al. 2018) due to a high overlap of space, habitat use, and denning behavior, including the shared use of den sites (Kowalczyk et al. 2008). In contrast to social mammals, the rate of encounters between individuals of solitary species was much lower and often limited to a few specific periods such as the mating season (Arlian 1989; Schmidt et al. 1997).

\section{Non-native invasive mammal species}

One of the largest pillars of invasion ecology is understanding what happens to parasite faunas when host species become 
established in a new region (Keogh et al. 2017; KołodziejSobocińska et al. 2018a; Laurimaa et al. 2016; Poulin 2017; Stricker et al. 2016). Commonly debated questions include: Which parasites are prevalent in native ranges but absent in new territories, and vice versa? Do some parasites pose a particular threat to local fauna and to human health in invasive ranges? In Europe, invasive non-native species (INNS) such as raccoon dogs, raccoons, and American mink are known to be important vectors of multiple zoonotic agents, of which some (e.g., Echinococcus multilocularis, Toxocara spp., Trichinella spp., and Alaria spp.) are highly pathogenic for humans (Bagrade et al. 2016; Cybulska et al. 2018; Hurníková et al. 2016; Laurimaa et al. 2016; MachnickaRowińska et al. 2002). Carnivores often act as definitive hosts that carry reproductive adults and shed eggs into the environment. Humans become intermediate, paratenic, or "dead end" host for these parasites because larval stages settled in human organs and tissues cause severe pathological changes and serious health consequences (Antolova et al. 2014; Chen et al. 2018; Kern et al. 2003; Nahorski et al. 2013). The Enemy Release Hypothesis (ERH) is one of the most important hypotheses explaining successful introduction and rapid spread of INNS (Dobson 1988; Elton 1958). Many studies have confirmed the possibility of escape from parasites, having shown that parasite species richness or prevalence is lower in host populations inhabiting invaded ranges compared to those in native ranges (Colautti et al. 2004; Torchin and Mitchell 2004). Yet the question remains: for how long? A recent study revealed that following American mink introduction to an invaded range, parasite abundance in the invasive mammal increased significantly for only 20 years (KołodziejSobocińska et al. 2018a). This suggests that INNS escape from parasite pressure for a shorter duration than expected (Gendron et al. 2012). INNS that escape their native range may benefit not only from reduced parasite pressure at the beginning of the invasion, but also from relaxed selection for costly immune response, which promotes reallocation of available resources toward growth, reproduction, and survival. As a result, invasive hosts may be less infected but —on the other hand - more susceptible to infection due to the weakening of defense mechanisms (Keogh et al. 2017).

\section{Non-native invasive parasite species}

According to Lymbery et al. (2014), alien parasites can be divided into two groups: cointroduced parasites which have been transported with an alien host to a new territory and coinvading parasites which have been cointroduced and then spread to new, native hosts. Cointroductions of parasites with alien hosts occur over a wide range of parasite and host taxa; however, most examples came from non-mammalian hosts (Britton et al. 2011; Ewen et al. 2012; Gaither et al. 2013; Lymbery et al. 2014; Poulin et al. 2011). Nearly $80 \%$ of cointroduced alien parasites switch to coinvaders. "Pathogen pollution" occurs when coinvading parasites that have been successfully transmitted from alien hosts colonizing new territories to native hosts lead to emergence of new disease in the native species (Daszak et al. 2000; Taraschewski 2006). Alien host populations may benefit from this. If those parasites subsequently infect and cause population declines in native species, the alien host population may be more likely to establish and spread as a result. This idea was discussed by Price et al. (1986) and is known as the Novel Weapon Hypothesis. There are many documented examples of alien parasite introduction to native European terrestrial mammals. Parasitic alien terrestrial arthropods occur in small mammals inhabiting Bulgaria (Kanchev et al. 2012). In Italy, native red squirrels coinhabiting with gray squirrels are more likely to be infected by gastrointestinal helminths, including the alien North American nematode Strongyloides robustus (Romeo et al. 2015). The introduction of Asian sika deer (Cervus nippon) has led to rapid spread of the alien invasive bloodsucking nematode Ashworthius sidemi in European bison (Bison bonasus) populations in Poland (Dróżdż et al. 1998; Kołodziej-Sobocińska et al. 2016a). Finally, Trichinella spiralis was introduced in Italy, probably from Eastern Europe by hunters, hunting dogs, or immigrants who illegally carried infected meat in their personal baggage (Garbarino et al. 2017).

\section{Biological factors}

\section{Sex, breeding status, and sexual selection}

Sex differences in parasite prevalence or intensity are commonly observed (Poulin 1996). Sex-biased parasitism may be due to ecological, behavioral, or physiological differences between males and females (Zuk and McKean 1996). Malebiased parasitism is a common phenomenon in vertebrateparasite systems (Grear et al. 2009; Poulin 1996), but is not universal (Fuxjager et al. 2011; Kiffner et al. 2013). Male contact with parasites is often more likely than in females (Klein 2004); for example, American mink males are larger, consume more diverse food, and disperse over longer distances (Oliver et al. 2016; Zalewski and Bartoszewicz 2012). Male-biased infection has alternatively been explained by the Immunocompetence Handicap Hypothesis, which suggests an immunosuppressive effect of testosterone that increases susceptibility to infection (Folstad and Karter 1992; Klein 2004). The elevated testosterone level during the breeding season reduces the immune response and accelerates an increase in infection intensity (Grear et al. 2009). However, the lower A. sidemi infection intensity observed in European bison bulls (Kołodziej-Sobocińska et al. 2016a) stands in opposition to the widely observed patterns 
of the higher susceptibility of males to parasitosis (Alexander and Stimson 1988; Klein 2004; Zuk and McKean 1996). It has been suggested that behavioral traits may be responsible for the lower parasitic load in European bison bulls, as European bison males live solitarily or in small groups, in contrast to subadults and females with calves (Krasińska and Krasiński 1995; Krasińska et al. 2000). In addition, pregnant and lactating females are immunosuppressed and therefore more susceptible to infection (Krishnan et al. 1996; Lloyd 1983). Apart from reproductive status, host immunity may also vary seasonally in relation to stress, food availability, photoperiod, etc. (Martin et al. 2008). Time of the mammal host parturition may also influence parasite spread and transmission dynamics. Synchrony in parturition concentrates young at times of resource abundance (Sinclair et al. 2000), adding a seasonal pulse of susceptible, immunologically nave hosts for parasites in the population (Altizer et al. 2006).

\section{Age}

The level of infection is associated with a host's age (Bush et al. 2001; Cornell et al. 2008), and examination of how parasitism changes with host age can provide insight into the existence of host-acquired immunity and age-dependent variation in host exposure to parasites (Woolhouse 1998). Thomas et al. (1995) argued that older individuals are less heavily infected because they may cease to acquire parasites as a consequence of changes in feeding or behavioral patterns, habitat utilization, or immunity acquisition. In most systems, however, young and subadult animals with immature immune systems are most susceptible to infection and disease and spread a higher number of infective eggs into the environment through their feces (e.g., Cornell et al. 2008; Kethineni et al. 2006; Treboganova 2010; Woolhouse 1998). The study by Cornell et al. (2008) revealed that in Scottish populations of European rabbit (Oryctolagus cuniculus) the effectiveness of hosts' immune response to the gastrointestinal nematode Trichostrongylus retortaeformis possibly acts, among others, through a maternal effect dependent on the European rabbit's month of birth. Cohorts of rabbits born in different months show the characteristic humpbacked relationship between parasite intensity and host age with the lowest parasite intensity in the youngest individuals. This could be a result of short exposure time of the host to the parasite as well as availability of maternal antibodies, which provide immunological protection (Hurley and Theil 2011; Jackson and Nazar 2006). Breastfed, young mammals should be better protected against diseases because they get maternal antibodies with milk. This is not always true, because some parasites, e.g., Toxocara spp., can be transmitted to puppies and kittens with the mother's milk, and during pregnancy through the placenta (Coati et al. 2004; Lee et al. 1976). By adulthood, animals have usually developed a stronger immunity and harbor lower infection levels (Kethineni et al. 2006). However, this pattern is not always confirmed. In Arvicola terrestris, an intermediate host for $E$. multilocularis, infections accumulate with increasing age in single vole generations and prevalence increases (Burlet et al. 2011). Similar to E. multilocularis, Taenia taeniaeformis causes lifelong infections in intermediate hosts and is more prevalent in older animals (Theis and Schwab 1992). This pattern is probably true also for other intermediate hosts, when larval stages accumulate in organs and tissue throughout the host life.

\section{Body condition, health, and immunocompetence}

Body condition metrics are often used to assess costs of parasitic infections in wildlife (Sánchez et al. 2018). However, the relationship between infection intensity and body condition is not well understood. It has been suggested that individuals in poor condition could be a "bad choice" for parasites due to the lack of available resources (Bize et al. 2008; Schulte-Hostedde and Elsasser 2011). However, parasites may negatively influence the body condition of their hosts (Turgeon et al. 2018; Winternitz et al. 2012), e.g., mink body condition has been negatively associated with nematode abundances in the gastrointestinal tract (Kołodziej-Sobocińska et al. 2018a). The deterioration of the body condition may be accelerated because individuals in poor condition are unable to control parasitic infection by mounting sufficient immune defenses (Martin et al. 2003). Body condition has been empirically linked with survival probability and reproductive success in many taxa, including carnivores (Schulte-Hostedde et al. 2005). In some studies of parasite-wildlife interactions, experimental manipulations are needed to confirm directional relationships and point to underlying mechanisms (Sánchez et al. 2018). For example, treating wild reindeer with anthelmintics increased their body condition, revealing negative relationships between parasitic load and body mass, fat deposition, and fecundity (Stien et al. 2002).

\section{Anthropogenic factors}

\section{Supplementary feeding}

In large herbivore management, supplementary feeding is mainly intended to reduce herbivore impact on agriculture, to enhance body condition and reproductive performance, or to supply endangered animals with food or water in crucial periods of their annual life cycle (Kozak et al. 1995; Loarie et al. 2009). However, it is known that supplementary feeding may have negative long-term effects on wildlife populations (Murray et al. 2016), including increasing parasite transmission in wild boar (Sus scrofa) (Oja et al. 2017), European 
bison (Kołodziej-Sobocińska et al. 2016a, d; Pyziel et al. 2011; Radwan et al. 2010), and other wild mammals (Sorensen et al. 2014). Oja et al. (2017) showed that the effects of supplementary feeding on gastrointestinal parasite infections in wild boar depend on the life cycle of the parasite species, as well as on environmental factors that affect survival and accumulation of oocysts and eggs at feeding sites. An additional effect of supplementary feeding was increased density of wild boar, which promotes the transmission of parasites with a direct life cycle (Oja et al. 2017). An annual survey of parasite eggs and oocyst excretion from European bison dung showed an increase in their prevalence and abundance during winter months, when supplementary feeding is provided (Kołodziej-Sobocińska et al. 2016d; Pyziel et al. 2011). This indicates a strong need to modify management practices in order to scatter herds, increase animal ranges, lower animal densities, and consequently reduce parasite transmission.

\section{Introduction, reintroduction, translocation, and conservation programs}

Risk factors for disease emergence in introduction, reintroduction, and conservation programs are complex and often neglected (Cunningham 1996; Scott 1988; Viggers et al. 1993). The translocation of wildlife for conservation, agriculture, and hunting occurs on a global scale, with an inherent risk of wildlife species exposure to exotic infectious agents (Daszak et al. 2000). Diseases are often a real threat to rare and endangered species; thus, the importance of diseases and their impact on reintroduced animals should be taken into account (Viggers et al. 1993). Reduced exposure to natural antigens and loss of immunogenetic variation during captive breeding may impair the survival probability of released animals (Cunningham 1996; Mathews et al. 2006; Viggers et al. 1993). Another issue is the potential transfer of pathogens into previously unexposed wild populations in often sensitive, protected areas (Barrio et al. 2012; Daszak et al. 2000; Kołodziej-Sobocińska et al. 2018b; Vadlejch et al. 2016). For example, the successful introduction of wild alpine marmot (Marmota marmota) in the Pyrenees, Iberian Peninsula, Spain, is associated with various threats from this introduced species (Barrio et al. 2012). Alpine marmots are likely to impact Pyrenean grasslands (grazing, burrowing), alter Pyrenean food webs, and act as vectors of parasites and diseases (Barrio et al. 2012). Preliminary studies revealed that the introduced alpine marmots have fewer parasites in the Pyrenees than they have in their native range; however, some of the alpine marmot parasite species were new to the Pyrenees, e.g., Calodium hepaticum, Ctaenotenia marmotae, Eimeria marmotae, and E. arctomysi (Gortázar et al. 1996; Riba and Tena 1999). Thus, the potential transmission of parasites introduced with alpine marmots to other species in the Pyrenees should be considered. Parasites can be also introduced with translocated captive mammals. Recently, the invasive nematode $A$. sidem $i$ was introduced to the Czech Republic with European bison translocated there from BPF, NE Poland (Vadlejch et al. 2016). In such situations, an effective procedure for animal deworming is necessary to avoid parasite transmission into new territories. On the other hand, treatment of animals prior to release may not be beneficial because it may reduce their levels of immunity to disease (Faria et al. 2010; Viggers et al. 1993). This is especially important if such pathogens are present in wild populations, e.g., regularly dewormed captive mammals may have no chance of acquiring immunity against parasites that they come into contact with upon release. It has been proposed that when there are parasites present in wild populations to which captive animals have not been exposed, it may be advisable to provide low-level exposure in captivity to develop some immunity (Viggers et al. 1993). Moreover, releasing captive-bred animals into the wild can increase their levels of stress, which could make them more susceptible to infection (Dickens et al. 2010). Thus, the pathological effects of infectious agents further debilitate released animals (Viggers et al. 1993; Wakelin 1978).

\section{Zoonoses}

Wildlife is now recognized as an important source of emerging human pathogens, including parasites (Daszak et al. 2000; Jones et al. 2008). Among emerging and reemerging infectious agents that people can acquire from wildlife, viruses and bacteria are the subject of intensive study. Unfortunately, much less attention is paid to parasitic diseases (Polley 2005), possibly because their effects are less dramatic, with fewer sudden outbreaks involving substantial human mortality. However, numerous wildlife-derived parasitic diseases of zoonotic potential have recently been of particular interest in Europe, e.g., Baylisascaris procyonis, Echinococcus multilocularis, Alaria spp., Toxocara spp., and Toxoplasma gondii (see details in Table 2). Among wild hosts for zoonotic parasites, carnivores are identified as the most likely source of human infection (43\% of pathogens), with ungulates (39\%), rodents (23\%), and non-human primates (13\%) next in order (Polley 2005). The most common zoonoses transmitted from animals to humans are diseases caused by viruses (Polley 2005). However, among all groups of pathogens (viruses, bacteria, fungi, parasites, etc.), parasitic protozoa are second after viruses in being the primary cause of zoonotic diseases, with helminths also playing a lesser but still formidable role in disease transmission (Polley 2005). The ways in which humans acquire zoonotic parasites are complex. Definitive hosts for parasites such as Echinococcus multilocularis shed parasite eggs into the environment; this further leads to a persistent source of infection not only for intermediate hosts like rodents, but also for humans as incidental hosts (Bastien et al. 
Table 2 Selected wildlife-derived zoonotic parasitic diseases occurring in Europe with the examples of recent study (since 2000)

\begin{tabular}{|c|c|c|c|}
\hline Parasite & Wild mammalian host & Localization & References \\
\hline \multicolumn{4}{|l|}{ Protozoa } \\
\hline \multirow[t]{4}{*}{ Babessia spp. } & Red fox & Austria & Duscher et al. (2017) \\
\hline & Brown hare & Italy & Rocchigiani et al. (2018) \\
\hline & Red fox & Romania & Daskalaki et al. (2018) \\
\hline & Red fox & Spain & Checa et al. (2018) \\
\hline \multirow{4}{*}{$\begin{array}{l}\text { Toxoplasma } \\
\text { gondii }\end{array}$} & Red fox & France & Bastien et al. (2018) \\
\hline & Wild boar, small rodents & Germany & Beltrán-Beck et al. (2012); Krucken et al. (2017) \\
\hline & Wild boar & Italy & Gazzonis et al. (2018) \\
\hline & Red fox & Poland & Karbowiak et al. (2010) \\
\hline \multicolumn{4}{|l|}{ Helminths } \\
\hline \multicolumn{4}{|l|}{ Nematoda } \\
\hline \multirow{3}{*}{$\begin{array}{l}\text { Baylisascaris } \\
\text { procyonis }\end{array}$} & Raccoon & Austria & Duscher et al. (2017) \\
\hline & Raccoon & Germany & Beltrán-Beck et al. (2012); Rentería-Solís et al. (2018a) \\
\hline & Raccoon & Poland & Popiołek et al. (2011) \\
\hline \multirow{4}{*}{$\begin{array}{l}\text { Dirofilaria } \\
\text { spp. }\end{array}$} & Red fox & Austria & Duscher et al. (2017) \\
\hline & Brown bear & Greece & Papadopoulos et al. (2017) \\
\hline & Golden jackal, red fox, wildcat, wolf, least weasel & Romania & Ionica et al. (2017) \\
\hline & River otter, golden jackal, red fox, wolf, wildcat & Serbia & Penezić et al. $(2014,2018)$ \\
\hline \multirow[t]{12}{*}{ Toxocara spp. } & Red fox & Austria & Duscher et al. (2017) \\
\hline & Red fox, raccoon dog, wolf & Belarus & $\begin{array}{l}\text { Chen et al. (2018); Shimalov and Shimalov (2000, 2002a, } \\
\text { 2003) }\end{array}$ \\
\hline & Red fox, raccoon dog & Denmark & Al-Sabi et al. (2014); Chen et al. (2018) \\
\hline & Raccoon dog, small rodents & Germany & Krucken et al. (2017); Sutor et al. (2014) \\
\hline & Red fox & $\begin{array}{l}\text { Great } \\
\text { Britain }\end{array}$ & Chen et al. (2018); Smith et al. (2003) \\
\hline & Red fox & Ireland & Chen et al. (2018); Stuart et al. (2013) \\
\hline & Red fox, wildcat & Italy & Chen et al. (2018); Magi et al. (2009); Napoli et al. (2016) \\
\hline & Raccoon dog & Lithuania & Bružinskaitè-Schmidhalter et al. (2011); Sutor et al. (2014) \\
\hline & Lynx, red fox, wolf, pine marten & Poland & $\begin{array}{l}\text { Górski et al. (2006); Karamon et al. (2018); } \\
\text { Kołodziej-Sobocińska et al. (2018c) }\end{array}$ \\
\hline & Red fox, Iberian wolf & Portugal & Figueiredo et al. (2016) \\
\hline & Red fox & Slovenia & Chen et al. (2018); Vergles Rataj et al. (2013) \\
\hline & Red fox & Switzerland & Chen et al. (2018); Reperant et al. (2007) \\
\hline \multirow{10}{*}{$\begin{array}{l}\text { Trichinella } \\
\text { spp. }\end{array}$} & Red fox, wild boar & Austria & Duscher et al. (2017) \\
\hline & $\begin{array}{l}\text { Raccoon dog, red fox, stoat, least weasel, river otter, } \\
\text { wolf, polecat, American mink }\end{array}$ & Belarus & $\begin{array}{l}\text { Pozio (2000); Shimalov et al. (2000); Shimalov and } \\
\text { Shimalov (2000, 2001a, b, 2002a, b, 2003); Sutor et al. } \\
\text { (2014) }\end{array}$ \\
\hline & Red fox, raccoon dog & Estonia & Karssin et al. (2017) \\
\hline & Raccoon dog & Finland & Oivanen et al. (2002); Sutor et al. (2014) \\
\hline & Raccoon dog & Germany & Pannwitz et al. (2010); Sutor et al. (2014) \\
\hline & Wild boar & Italy & Garbarino et al. (2017) \\
\hline & Red fox, raccoon dog & Lithuania & Bružinskaitè-Schmidhalter et al. (2011) \\
\hline & Raccoon, wolf, American mink, wild boar, lynx & Poland & $\begin{array}{l}\text { Bień et al. (2016); Bilska-Zając et al. (2017); Hurníková } \\
\text { et al. (2016); Cybulska et al. (2018); } \\
\text { Kołodziej-Sobocińska et al. (2018c) }\end{array}$ \\
\hline & Raccoon dog & Russia & Pozio (2000); Sutor et al. (2014) \\
\hline & Red fox, golden jackal & Serbia & Dmitric et al. (2017) \\
\hline
\end{tabular}


Table 2 (continued)

\begin{tabular}{|c|c|c|c|}
\hline Parasite & Wild mammalian host & Localization & References \\
\hline \multicolumn{4}{|l|}{ Trematoda } \\
\hline \multirow[t]{7}{*}{ Alaria spp. } & Wild boar, red fox & Austria & Duscher et al. (2017) \\
\hline & $\begin{array}{l}\text { Raccoon dog, red fox, stoat, least weasel, river otter, } \\
\text { wolf, striped field mouse, polecat, American mink, } \\
\text { European mole, water shrew }\end{array}$ & Belarus & $\begin{array}{l}\text { Sutor et al. (2014); Shimalov (2002, 2017); Shimalov and } \\
\text { Shimalov (2000, 2001a, 2001b, 2001c, 2002a, 2002b, } \\
\text { 2003); Shimalov et al. (2000) }\end{array}$ \\
\hline & Raccoon, raccoon dog & Germany & Rentería-Solís et al. (2013); Sutor et al. (2014) \\
\hline & Wild boar & Italy & Gazzonis et al. (2018) \\
\hline & Red fox, raccoon dog & Lithuania & Bružinskaitė-Schmidhalter et al. (2011) \\
\hline & $\begin{array}{l}\text { Wild boar, badger, red fox, river otter, wolf, American } \\
\text { mink, lynx }\end{array}$ & Poland & $\begin{array}{l}\text { Górski et al. (2006); Karamon et al. (2018); Rentería-Solís } \\
\text { et al. (2018b); Szczęsna et al. (2008) }\end{array}$ \\
\hline & European mink & Romania & Tăbăran et al. (2013) \\
\hline \multicolumn{4}{|l|}{ Cestoda } \\
\hline \multirow{9}{*}{$\begin{array}{l}\text { Echinococcus } \\
\text { multilocula- } \\
\text { ris }\end{array}$} & Red fox, rodents & Austria & Duscher et al. (2017) \\
\hline & Red fox & Belarus & Shimalov and Shimalov (2003) \\
\hline & Red fox & France & Bastien et al. (2018) \\
\hline & Raccoon dog & Germany & Sutor et al. (2014) \\
\hline & Red fox, raccoon dog & Latvia & Bagrade et al. (2016); Sutor et al. (2014) \\
\hline & Red fox, raccoon dog & Lithuania & Bružinskaitė-Schmidhalter et al. (2011) \\
\hline & Red fox, raccoon dog & Poland & $\begin{array}{l}\text { Karamon et al. (2014); Nahorski et al. (2013); } \\
\text { Machnicka-Rowińska et al. (2002) }\end{array}$ \\
\hline & Red fox, wolf & Slovakia & Antolova et al. (2009, 2014); Martínek et al. (2001) \\
\hline & Red fox & Switzerland & Reperant et al. (2007) \\
\hline \multirow[t]{3}{*}{ Spirometra sp. } & $\begin{array}{l}\text { European mink, American mink, river otter, raccoon } \\
\text { dog, stoat, least weasel, red fox, wolf, polecat, } \\
\text { European mole }\end{array}$ & Belarus & $\begin{array}{l}\text { Anisimova (2004); Shimalov and Shimalov (2000, 2001a, } \\
\text { 2001b, 2001c, 2002a, 2002b, 2003); Shimalov et al. } \\
\text { (2000) }\end{array}$ \\
\hline & European hedgehog, stone marten, polecat, brown rat & Italy & Pampiglione et al. (2003) \\
\hline & Badger, wild boar, lynx & Poland & $\begin{array}{l}\text { Kołodziej-Sobocińska et al. (2014a, 2016c, 2018c); } \\
\text { Szczęsna et al. (2008) }\end{array}$ \\
\hline
\end{tabular}

Latin names of mammal species used in alphabetical order: American mink (Neovison vison), badger (Meles meles), brown bear (Ursus arctos), brown hare (Lepus europeaus), brown rat (Mus decumanus), European hedgehog (Erinaceus europeaus), European mink (Mustela lutreola), European mole (Talpa europaea), golden jackal (Canis aureus), Iberian wolf (Canis lupus signatus), least weasel (Mustela nivalis), lynx (Lynx lynx), pine marten (Martes martes), polecat (Mustela putorius), raccoon (Procyon lotor), raccoon dog (Nyctereutes procyonoides), red fox (Vulpes vulpes), river otter (Lutra lutra), stoat (Mustela erminea), stone marten (Martes foina), striped field mouse (Apodemus agrarius), water shrew (Neomys fodien spennant), wild boar (Sus scrofa), wildcat (Felis silvestris), wolf (Canis lupus)

2018; Karamon et al. 2014; Lempp et al. 2017). Some parasites settle in the muscle tissue of hosts, e.g., Alaria spp., Trichinella spp., Spirometra sp., and Toxoplasma spp.; thus, they can be ingested by humans eating raw or inadequately cooked meat (Dmitric et al. 2018; Gazzonis et al. 2018; Kołodziej-Sobocińska et al. 2016c). It is important to carry out parasitological monitoring of wild animals, especially those that are hunted or live near human settlements, and therefore have the potential to become a threat to humans. For parasites acquired from food obtained from wild animals, the ability to accurately predict risk of infection is also influenced by cultural traditions for food preparation that may affect parasite viability (Polley 2005). Unfortunately, there is an absence of adequately detailed data on key aspects of the ecology of many zoonotic parasites in wildlife; therefore, only general predictions of risk of human infection are possible. The importance of public education for prevention and control of human infections is neglected, which often leads to new outbreaks of zoonotic parasitic diseases acquired from wildlife, especially in poorly developed countries.

Human activity may be important for opening both encounter and compatibility filters by many ways: changing ecosystems (climate change, urbanization), providing additional resources (supplementary feeding, pastures), changing host behavior (destruction of habitats, translocations), changing the level of host defense (stress, emerging diseases), and others. Not only "natural" factors shape the host-parasite associations in wildlife. Human impact plays an important, and often negative, role in wild populations also through opening "natural filters" that normally control parasite transmission in natural conditions. 


\section{Conclusions}

Herein, I have summarized the current state of knowledge about factors that affect dynamics and spread of parasites in populations of wild terrestrial mammals in Europe. These factors form a complex network of interdependencies that influence host-parasite coexistence (see Fig. 1). It should be emphasized that human activity and natural factors are very important. I hope that this review paper allowed for a better understanding of parasitic disease persistence in wildlife and indicates the need to further develop knowledge on this topic, not only for academic reasons, but also for the benefit of use in the management of wild mammal species and disease control in nature.

Acknowledgements I would like to thank the Editor and two anonymous reviewers for the comprehensive and accurate comments which allowed me to improve the manuscript. I would also like to thank Anita Michalak for English language correction.

Open Access This article is distributed under the terms of the Creative Commons Attribution 4.0 International License (http:// creativecommons.org/licenses/by/4.0/), which permits unrestricted use, distribution, and reproduction in any medium, provided you give appropriate credit to the original author(s) and the source, provide a link to the Creative Commons license, and indicate if changes were made.

Publisher's note Springer Nature remains neutral with regard to jurisdictional claims in published maps and institutional affiliations.

\section{References}

Alexander J, Stimson WH (1988) Sex hormones and the course of parasitic infection. Parasitol Today 4(7):189-193. https://doi.org/10. 1016/0169-4758(88)90077-4

Al-Sabi MN, Halasa T, Kapel CM (2014) Infections with cardiopulmonary and intestinal helminths and sarcoptic mange in red foxes from two different localities in Denmark. Acta Parasitol 59:98-107. https://doi.org/10.2478/s11686-014-0214-6

Altizer S, Dobson A, Hosseini P, Hudson P, Pascual M, Rohani P (2006) Seasonality and the dynamics of infectious diseases. Ecol Lett 9(4): 467-484. https://doi.org/10.1111/j.1461-0248.2005.00879.x

Altizer S, Bartel R, Han BA (2011) Animal migration and infectious disease risk. Science 331(6015):296-302. https://doi.org/10.1126/ science. 1194694

Anderson RM (1982) The population dynamics of infectious diseases: theory and applications, Population and Community Biology Series. Springer-Science + Business Media, B.V, Dordrecht

Anderson RM, May RM (1978) Regulation and stability of host-parasite population interactions. 1. Regulatory processes. J Anim Ecol 47(1): 219-247. https://doi.org/10.2307/3933

Anderson RM, May RM (1979) Population biology of infectious diseases. Nature 280(5721):361-367. https://doi.org/10.1038/ 280361a0

Anisimova EI (2004) Study on the European mink Mustela lutreola helminthocenoses in connection with the American mink M. vison expansion in Belarus: story of the study and review of the results. Helminthologia 41(4):193-196
Antolova D, Reiterova K, Miterpakova M, Dinkel A, Dubinsky P (2009) The first finding of Echinococcus multilocularis in dogs in Slovakia: an emerging risk for spreading of infection. Zoonoses Public Health 56(2):53-58. https://doi.org/10.1111/j.1863-2378.2008.01154.x

Antolova D, Miterpakova M, Radonak J, Hudackova D, Szilagyiova M, Zacek M (2014) Alveolar echinococcosis in a highly endemic area of northern Slovakia between 2000 and 2013. Eurosurveillance 19(34): 13-20

Arlian LG (1989) Biology, host relations, and epidemiology of Sarcoptes scabiei. Annu Rev Entomol 34:139-161. https://doi.org/10.1146/ annurev.en.34.010189.001035

Auld S, Tinkler SK, Tinsley MC (2016) Sex as a strategy against rapidly evolving parasites. Proc R Soc B-Biol Sci 283:20162226. https:// doi.org/10.1098/rspb.2016.2226

Bagrade G, Deksne G, Ozolina Z, Howlett SJ, Interisano M, Casulli A, Pozio E (2016) Echinococcus multilocularis in foxes and raccoon dogs: an increasing concern for Baltic countries. Parasit Vectors 9: 615. https://doi.org/10.1186/s13071-016-1891-9

Barger IA, Siale K, Banks DJD, Lejambre LF (1994) Rotational grazing for control of gastrointestinal nematodes of goats in a wet tropical environment. Vet Parasitol 53(1-2):109-116. https://doi.org/10. 1016/0304-4017(94)90023-X

Barrio IC, Herrero J, Bueno CG, Lopez BC, Aldezabal A, CamposArceiz A, Garcia-Gonzalez R (2012) The successful introduction of the alpine marmot Marmota marmota in the Pyrenees, Iberian Peninsula, Western Europe. Mamm Rev 43(2):142-155. https://doi. org/10.1111/j1365-2907.2012.0212.x

Bastien M, Vaniscotte A, Combes B, Umhang G, Germain E, Gouley V, Pierlet A, Quintaine T, Forin-Wiart MA, Villena I, Aubert D, Boue F, Poulle ML (2018) High density of fox and cat faeces in kitchen gardens and resulting rodent exposure to Echinococcus multilocularis and Toxoplasma gondii. Folia Parasitol 65:002. https://doi.org/10.14411/fp.2018.002

Begon M, Telfer S, Smith MJ, Burthe S, Paterson S, Lambin X (2009) Seasonal host dynamics drive the timing of recurrent epidemics in a wildlife population. Proc R Soc B-Biol Sci 276(1662):1603-1610. https://doi.org/10.1098/rspb.2008.1732

Beldomenico PM, Telfer S, Gebert S, Lukomski L, Bennett M, Begon M (2008) Poor condition and infection: a vicious circle in natural populations. Proc R Soc B-Biol Sci 275(1644):1753-1759. https://doi. org/10.1098/rspb.2008.0147

Beltrán-Beck B, García J, Gortázar C (2012) Raccoons in Europe: disease hazards due to the establishment of an invasive species. Eur J Wildl Res 58:5-15. https://doi.org/10.1007/s10344-011-0600-4

Bień J, Moskwa B, Cabaj W (2010) In vitro isolation and identification of the first Neospora caninum isolate from European bison (Bison bonasus bonasus L.). Vet Parasitol 173(3-4):200-205. https://doi. org/10.1016/j.vetpar.2010.06.038

Bień J, Moskwa B, Goździk K, Cybulska A, Kornacka A, Welc M, Popiołek M, Cabaj W (2016) The occurrence of nematodes of the genus Trichinella in wolves (Canis lupus) from the Bieszczady Mountains and Augustowska Forest in Poland. Vet Parasitol 231: 115-117. https://doi.org/10.1016/j.vetpar.2016.04.010

Bilska-Zając E, Różycki M, Chmurzyńska E, Antolak E, Próchniak M, Gradziel-Krukowska K, Karamon J, Sroka J, Zdybel J, Cencek T (2017) First case of Trichinella nativa infection in wild boar in Central Europe - molecular characterization of the parasite. Parasitol Res 116(6):1705-1711. https://doi.org/10.1007/s00436017-5446-6

Bize P, Jeanneret C, Klopfenstein A, Roulin A (2008) What makes a host profitable? Parasites balance host nutritive resources against immunity. Am Nat 171(1):107-118. https://doi.org/10.1086/523943

Bohm M, Palphramand KL, Newton-Cross G, Hutchings MR, White PCL (2008) The spatial distribution of badgers, setts and latrines: the risk for intra-specific and badger-livestock disease transmission. 
Ecography 31(4):525-537. https://doi.org/10.1111/j.0906-7590. 2008.05314.x

Bonesi L, Palazon S (2007) The American mink in Europe: status, impacts, and control. Biol Conserv 134(4):470-483. https://doi.org/10. 1016/j.biocon.2006.09.006

Bonsall MB, Hassell MP (1999) Parasitoid-mediated effects: apparent competition and the persistence of host-parasitoid assemblages. Res Popul Ecol 41(1):59-68. https://doi.org/10.1007/pl00011983

Britton JR, Pegg J, Williams CF (2011) Pathological and ecological host consequences of infection by an introduced fish parasite. PLoS One 6:e26365. https://doi.org/10.1371/journal.pone.0026365

Brooks DR, Hoberg EP, Gardner SL, Boeger W, Galbreath KE, Herczeg D (2014) Finding them before they find us: informatics, parasites and environments in accelerating climate change. Comp Parasitol 81(2):155-164. https://doi.org/10.1654/4724b.1

Brown LM, Hall RJ (2018) Consequences of resource supplementation for disease risk in a partially migratory population. Philos Trans R Soc B-Biol Sci 373:20170095. https://doi.org/10.1098/rstb.2017. 0095

Bružinskaitè-Schmidhalter R, Šarkūnas M, Malakauskas A, Mathis A, Torgerson P, Deplazes P (2011) Helminths of red foxes (Vulpes vulpes) and raccoon dogs (Nyctereutes procyonoides) in Lithuania. Parasitology 139:120-127. https://doi.org/10.1017/ S0031182011001715

Burlet P, Deplazes P, Hegglin D (2011) Age, season and spatio-temporal factors affecting the prevalence of Echinococcus multilocularis and Taenia taeniaeformis in Arvicola terrestris. Parasit Vectors 4:6. https://doi.org/10.1186/1756-3305-4-6

Bush AO, Fernandez JC, Esch GW, Seed JR (2001) Immunological, pathological, and biochemical aspects of parasitism. In: Bush AO, Fernandez JC, Esch GW, Seed JR (eds) Parasitism. The diversity and ecology of animal parasites. Cambridge Unversity Press, United Kingdom, pp 13-42

Butterworth EW, Beverleyburton M (1981) Observations on the prevalence and intensity of Capillaria spp. (Nematoda, Trichuroidea) in wild carnivora from Ontario, Canada. Proc Helminth Soc Washington 48(1):24-37

Cable J, Barber I, Boag B, Ellison AR, Morgan ER, Murray K, Pascoe EL, Sait SM, Wilson AJ, Booth M (2017) Global change, parasite transmission and disease control: lessons from ecology. Philos Trans R Soc Lond Ser B Biol Sci 372(1719):20160088. https://doi.org/10. 1098/rstb.2016.0088

Cattadori IM, Boag B, Bjornstad ON, Cornell SJ, Hudson PJ (2005) Peak shift and epidemiology in a seasonal host-nematode system. Proc R Soc B-Biol Sci 272(1568):1163-1169. https://doi.org/10.1098/rspb. 2004.3050

Chaneton EJ, Bonsall MB (2000) Enemy-mediated apparent competition: empirical patterns and the evidence. Oikos 88(2):380-394. https:// doi.org/10.1034/j.1600-0706.2000.880217.x

Checa R, Lopez-Beceiro AM, Barrera JP, Ortega N, Galvez R, Marino V, Gonzalez J, Olmeda AS, Fidalgo LE, Guadalupe M (2018) Babesia microti-like piroplasm (syn. Babesia vulpes) infection in red foxes (Vulpes vulpes) in NW Spain (Galicia) and its relationship with Ixodes hexagonus. Vet Parasitol 252:22-28. https://doi.org/10. 1016/j.vetpar.2018.01.011

Chen J, Liu Q, Liu GH, Zheng WB, Hong SJ, Sugiyama H, Zhu XQ, Elsheikha HM (2018) Toxocariasis: a silent threat with a progressive public health impact. Infect Dis Poverty 7:59. https://doi.org/10. 1186/s40249-018-0437-0

Coati N, Schnieder T, Epe C (2004) Vertical transmission of Toxocara cati Schrank 1788 (Anisakidae) in the cat. Parasitol Res 92:142146. https://doi.org/10.1007/s00436-003-1019-y

Colautti RI, Ricciardi A, Grigorovich IA, MacIsaac HJ (2004) Is invasion success explained by the enemy release hypothesis? Ecol Lett 7(8): 721-733. https://doi.org/10.1111/j.1461-0248.2004.00616.x
Combes C (1991) Evolution of parasite life cycles. In: Toft CA, Aeschlimann A, Bolis L (eds) Parasite-host associations. Coexistence or conflict? Oxford University Press, Oxford

Combes C (2001) Parasitism: the ecology and evolution of intimate interactions. The University of Chicago Press, Chicago

Cornell SJ, Bjornstad ON, Cattadori IM, Boag B, Hudson PJ (2008) Seasonality, cohort-dependence and the development of immunity in a natural host-nematode system. Proc R Soc B-Biol Sci 275(1634):511-518. https://doi.org/10.1098/rspb.2007.1415

Craft ME, Hawthorne PL, Packer C, Dobson AP (2008) Dynamics of a multihost pathogen in a carnivore community. J Anim Ecol 77(6): 1257-1264. https://doi.org/10.1111/j.1365-2656.2008.01410.x

Cunningham AA (1996) Disease risks of wildlife translocations. Conserv Biol 10(2):349-353. https://doi.org/10.1046/j.1523-1739.1996. 10020349.x

Curtis VA (2014) Infection-avoidance behaviour in humans and other animals. Trends Immunol 35(10):457-464. https://doi.org/10.1016/ j.it.2014.08.006

Cybulska A, Skopek R, Kornacka A, Popiołek M, Piróg A, Laskowski Z, Moskwa B (2018) First detection of Trichinella pseudospiralis infection in raccoon (Procyon lotor) in Central Europe. Vet Parasitol 254:114-119. https://doi.org/10.1016/j.vetpar.2018.03.007

Daskalaki AA, Ionica AM, Deak G, Gherman CM, D’Amico G, Pastrav IR, Matei IA, Domsa C, Mihalca AD (2018) Environmental factors influencing the distribution of "Theileria annae" in red foxes, Vulpes vulpes in Romania. Ticks Tick Borne Dis 9(3):660-664. https://doi.org/10.1016/j.ttbdis.2018.01.019

Daszak P, Cunningham AA, Hyatt AD (2000) Wildlife ecology - emerging infectious diseases of wildlife - threats to biodiversity and human health. Science 287(5452):443-449. https://doi.org/10.1126/ science. 287.5452 .443

Davidson RK, Licina T, Gorini L, Milner JM (2015) Endoparasites in a Norwegian moose (Alces alces) population - faunal diversity, abundance and body condition. Int J Parasitol Parasit Wildl 4(1):29-36. https://doi.org/10.1016/j.ijppaw.2014.12.005

Demiaszkiewicz A, Kuligowska I, Lachowicz J, Pyziel A, Moskwa B (2013) The first detection of nematodes Ashworthius sidemi in elk Alces alces (L.) in Poland and remarks of ashworthiosis foci limitations. Acta Parasitol 58(4):515-518. https://doi.org/10.2478/ s11686-013-0164-4

Dickens MJ, Delehanty DJ, Romero LM (2010) Stress: an inevitable component of animal translocation. Biol Conserv 143(6):13291341. https://doi.org/10.1016/j.biocon.2010.02.032

Dmitric M, Vidanovic D, Vaskovic N, Matovic K, Sekler M, Debeljak Z, Karabasil N (2017) Trichinella infections in red foxes (Vulpes vulpes) and golden jackals (Canis aureus) in six districts of Serbia. J Zoo Wildl Med 48(3):703-707. https://doi.org/10.1638/20160169.1

Dmitric M, Debeljak Z, Vidanovic D, Sekler M, Vaskovic N, Matovic K, Karabasil N (2018) Trichinella britovi in game meat linked to human trichinellosis outbreak in Serbia. J Parasitol 104(5):557-559. https://doi.org/10.1645/18-42

Dobson AP (1988) Restoring island ecosystems: the potential of parasites to control introduced mammals. Conserv Biol 2(1):31-39. https:// doi.org/10.1111/j.1523-1739.1988.tb00333.x

Dróżdż J, Demiaszkiewicz AW, Lachowicz J (1998) Ashworthius sidemi (Nematoda, Trichostrongylidae) a new parasite of the European bison Bison bonasus (L.) and the question of independence of A. gagarini. Acta Parasitol 43(2):75-80

Dróżdż J, Demiaszkiewicz AW, Lachowicz J (2003) Expansion of the Asiatic parasite Ashworthius sidemi (Nematoda, Trichostrongylidae) in wild ruminants in Polish territory. Parasitol Res 89(2):94-97. https://doi.org/10.1007/s00436-002-0675-7

Duscher T, Hodžić A, Glawischnig W, Duscher GG (2017) The raccoon dog (Nyctereutes procyonoides) and the raccoon (Procyon lotor) their role and impact of maintaining and transmitting zoonotic 
diseases in Austria, Central Europe. Parasitol Res 116(4):14111416. https://doi.org/10.1007/s00436-017-5405-2

Elton C (1958) The ecology of invasions by animals and plants. Methuen \& Co. Ltd, London

Ewen JG, Bensch S, Blackburn TM, Bonneaud C, Brown R, Cassey P, Clarke RH, Perez-Tris J (2012) Establishment of exotic parasites: the origins and characteristics of an avian malaria community in an isolated island avifauna. Ecol Lett 15:1112-1119. https://doi.org/10. $1111 / j .1461-0248.2012 .01833 . x$

Faria PJ, van Oosterhout C, Cable J (2010) Optimal release strategies for captive-bred animals in reintroduction programs: experimental infections using the guppy as a model organism. Biol Conserv 143(1): 35-41. https://doi.org/10.1016/j.biocon.2009.06.002

Figueiredo A, Oliveira L, Madeira de Carvalho L, Fonseca C, Torres T (2016) Parasite species of the endangered Iberian wolf (Canis lupus signatus) and a sympatric widespread carnivore. Int J Parasitol Parasit Wildl 5(2):164-167. https://doi.org/10.1016/j.ijppaw.2016. 04.002

Folstad I, Karter AJ (1992) Parasites, bright males, and the immunocompetence handicap. Am Nat 139(3):603-622. https://doi.org/10.1086/ 285346

Folstad I, Nilssen AC, Halvorsen O, Andersen J (1991) Parasite avoidance - the cause of post-calving migrations in Rangifer. Can J Zool 69(9):2423-2429. https://doi.org/10.1139/z91-340

Friesen OC, Roth JD, Graham LC (2015) Sex-biased parasitism in monogamous arctic foxes is driven by diet. J Mammal 96(2):417-424. https://doi.org/10.1093/jmammal/gyv043

Fuxjager MJ, Foufopoulos J, Diaz-Uriarte R, Marler CA (2011) Functionally opposing effects of testosterone on two different types of parasite: implications for the immunocompetence handicap hypothesis. Funct Ecol 25(1):132-138. https://doi.org/10.1111/j.13652435.2010.01784.x

Gaither MR, Aeby G, Vignon M, Meguro Y, Rigby M, Runyon C, Toonen RJ, Wood CL, Bowen BW (2013) An invasive fish and the time-lagged spread of its parasite across the Hawaiian archipelago. PLoS One:e56940. https://doi.org/10.1371/journal.pone. 0056940

Garbarino C, Interisano M, Chiatante A, Marucci G, Merli E, Arrigoni N, Cammi G, Ricchi M, Tonanzi D, Tamba M, La Rosa G, Pozio E (2017) Trichinella spiralis a new alien parasite in Italy and the increased risk of infection for domestic and wild swine. Vet Parasitol 246:1-4. https://doi.org/10.1016/j.vetpar.2017.08.021

Gazzonis AL, Villa L, Riehn K, Hamedy A, Minazzi S, Olivieri E, Zanzani SA, Manfredi MT (2018) Occurrence of selected zoonotic food-borne parasites and first molecular identification of Alaria alata in wild boars (Sus scrofa) in Italy. Parasitol Res 117(7): 2207-2215. https://doi.org/10.1007/s00436-018-5908-5

Gendron AD, Marcogliese DJ, Thomas M (2012) Invasive species are less parasitized than native competitors, but for how long? The case of the round goby in the Great Lakes-St. Lawrence Basin. Biol Invasions 14(2):367-384. https://doi.org/10.1007/s10530-0110083-y

Górski P, Zalewski A, Łakomy M (2006) Parasites of carnivorous mammals in Białowieża Primeval Forest. Wiad Parazytol 52(1):49-53

Gortázar C, Herrero J, García-Serrano A, Lucientes J, Luco DF (1996) Preliminary data on the parasitic fauna of the digestive system of Marmota marmota in the Western Pyrenees. In: Le Berre M, Ramousse R, Le Guelte L (eds) Biodiversity in marmots. International Marmot Network, Moscow, pp 105-108

Grear DA, Perkins SE, Hudson PJ (2009) Does elevated testosterone result in increased exposure and transmission of parasites? Ecol Lett 12(6):528-537. https://doi.org/10.1111/j.1461-0248.2009. 01306.x

Hart BL, Hart LA (2018) How mammals stay healthy in nature: the evolution of behaviours to avoid parasites and pathogens. Philos
Trans R Soc B-Biol Sci 373(1751). https://doi.org/10.1098/rstb. 2017.0205

Harvell CD, Mitchell CE, Ward JR, Altizer S, Dobson AP, Ostfeld RS, Samuel MD (2002) Ecology - climate warming and disease risks for terrestrial and marine biota. Science 296(5576):2158-2162. https:// doi.org/10.1126/science.1063699

Haukisalmi V, Laaksonen S, Oksanen A, Beckmen K, Halajian A, Yanagida T, Nakao M (2018) Molecular taxonomy and subgeneric classification of tapeworms of the genus Moniezia Blanchard, 1891 (Cestoda, Anoplocephalidae) in northern cervids (Alces and Rangifer). Parasitol Int 67(2):218-224. https://doi.org/10.1016/j. parint.2017.12.006

Herbison R, Lagrue C, Poulin R (2018) The missing link in parasite manipulation of host behaviour. Parasit Vectors 11:222. https://doi. org/10.1186/s13071-018-2805-9

Hines AM, Ezenwa VO, Cross P, Rogerson JD (2007) Effects of supplemental feeding on gastrointestinal parasite infection in elk (Cervus elaphus): preliminary observations. Vet Parasitol 148(3):350-355. https://doi.org/10.1016/j.vetpar.2007.07.006

Hoberg EP, Brooks DR (2015) Evolution in action: climate change, biodiversity dynamics and emerging infectious disease. Philos Trans R Soc of Lond B Biol Sci 370(1665):20130553. https://doi.org/10. 1098/rstb.2013.0553

Holmala K, Kauhala K (2006) Ecology of wildlife rabies in Europe. Mammal Rev 36(1):17-36. https://doi.org/10.1111/j.1365-2907. 2006.00078.x

Holmes CJ, Dobrotka CJ, Farrow DW, Rosendale AJ, Benoit JB, Pekins PJ, Yoder JA (2018) Low and high thermal tolerance characteristics for unfed larvae of the winter tick Dermacentor albipictus (Acari: Ixodidae) with special reference to moose. Ticks Tick-Borne Dis 9(1):25-30. https://doi.org/10.1016/j.ttbdis.2017.10.013

Hudson PJ, Cattadori M, Boag B, Dobson AP (2006a) Climate disruption and parasite-host dynamics: patterns and processes associated with warming and the frequency of extreme climatic events. J Helminthol 80(2):175-182. https://doi.org/10.1079/joh2006357

Hudson PJ, Dobson AP, Lafferty KD (2006b) Is a healthy ecosystem one that is rich in parasites? Trends Ecol Evol 21(7):381-385. https:// doi.org/10.1016/j.tree.2006.04.007

Hurley WL, Theil PK (2011) Perspectives on immunoglobulins in colostrum and milk. Nutrients 3(4):442-474. https://doi.org/10.3390/ nu3040442

Hurníková Z, Kołodziej-Sobocińska M, Dvorožňáková E, Niemczynowicz A, Zalewski A (2016) An invasive species as an additional parasite reservoir: Trichinella in introduced American mink (Neovison vison). Vet Parasitol 231:106-109. https://doi.org/ 10.1016/j.vetpar.2016.06.010

Ionica AM, Matei IA, D'Amico G, Ababai J, Daskalaki AA, Sandor AD, Enchache DV, Gherman CM, Mihalca AD (2017) Filarioid infections in wild carnivores: a multispecies survey in Romania. Parasit Vectors 10:332. https://doi.org/10.1186/s13071-017-2269-3

Jackson KM, Nazar AM (2006) Breastfeeding, the immune response, and long-term health. J Am Osteopath Assoc 106(4):203-207

Johnson PTJ, Hoverman JT (2012) Parasite diversity and coinfection determine pathogen infection success and host fitness. Proc Natl Acad Sci U S A 109(23):9006-9011. https://doi.org/10.1073/pnas. 1201790109

Jones KE, Patel NG, Levy MA, Storeygard A, Balk D, Gittleman JL, Daszak P (2008) Global trends in emerging infectious diseases. Nature 451(7181):990-993. https://doi.org/10.1038/nature06536

Kanchev K, Kamenov Y, Atanassova I, Davidova R, Tomov R (2012) Parasitic alien terrestrial arthropods on small mammals in northeastern and South Bulgaria. Bulg J Agricult Sci 18(6):965-970

Karamon J, Kochanowski M, Sroka J, Cencek T, Różycki M, Chmurzyńska E, Bilska-Zajac E (2014) The prevalence of Echinococcus multilocularis in red foxes in Poland - current results 
(2009-2013). Parasitol Res 113(1):317-322. https://doi.org/10. 1007/s00436-013-3657-z

Karamon J, Dąbrowska J, Kochanowski M, Samorek-Pieróg M, Sroka J, Różycki M, Bilska-Zając E, Zdybel J, Cencek T (2018) Prevalence of intestinal helminths of red foxes (Vulpes vulpes) in Central Europe (Poland): a significant zoonotic threat. Parasit Vectors 11: 436. https://doi.org/10.1186/s13071-018-3021-3

Karbowiak G, Majlathova V, Hapunik J, Pet'ko B, Wita I (2010) Apicomplexan parasites of red foxes (Vulpes vulpes) in northeastern Poland. Acta Parasitol 55:210-214. https://doi.org/10.2478/s11686010-0030-6

Karbowiak G, Demiaszkiewicz AW, Pyziel AM, Wita I, Moskwa B, Werszko J, Bień J, Goździk K, Lachowicz J, Cabaj W (2014) The parasitic fauna of the European bison (Bison bonasus) (Linnaeus, 1758) and their impact on the conservation. Part 2 . The structure and changes over time. Acta Parasitol 59(3):372-379. https://doi.org/10. 2478/s11686-014-0253-Z

Karssin A, Hakkinen L, Niin E, Peik K, Vilem A, Jokelainen P, Lassen B (2017) Trichinella spp. biomass has increased in raccoon dogs (Nyctereutes procyonoides) and red foxes (Vulpes vulpes) in Estonia. Parasit Vectors 10:609. https://doi.org/10.1186/s13071017-2571-0

Kavaliers M, Choleris E (2018) The role of social cognition in parasite and pathogen avoidance. Philos Trans R Soc B-Biol Sci 373: 20170206. https://doi.org/10.1098/rstb.2017.0206

Kelly DW, Paterson RA, Townsend CR, Poulin R, Tompkins DM (2009) Parasite spillback: a neglected concept in invasion ecology? Ecology 90(8):2047-2056. https://doi.org/10.1890/08-1085.1

Keogh CL, Miura O, Nishimura T, Byers JE (2017) The double edge to parasite escape: invasive host is less infected but more infectable. Ecology 98(9):2241-2247. https://doi.org/10.1002/ecy.1953

Kern P, Bardonnet K, Renner E, Auer H, Pawlowski Z, Ammann RW, Vuitton DA (2003) European echinococcosis registry: human alveolar echinococcosis, Europe, 1982-2000. Emerg Infect Dis 9(3): 343-349

Kethineni N, Brummer E, Stevens DA (2006) Susceptibility to pulmonary blastomycosis in young compared to adult mice: immune deficiencies in young mice. Med Mycol 44(1):51-60. https://doi.org/ $10.1080 / 13693780500220498$

Kiffner C, Stanko M, Morand S, Khokhlova IS, Shenbrot GI, Laudisoit A, Leirs H, Hawlena H, Krasnov BR (2013) Sex-biased parasitism is not universal: evidence from rodent-flea associations from three biomes. Oecologia 173:1009-1022. https://doi.org/10.1007/ s00442-013-2664-1

Klein SL (2004) Hormonal and immunological mechanisms mediating sex differences in parasite infection. Parasite Immunol 26(6-7):247264. https://doi.org/10.1111/j.0141-9838.2004.00710.x

Kołodziej-Sobocińska M, Miniuk M (2018) Sparganosis - neglected zoonosis and its reservoir in wildlife. Med Weter 74(4):224-227. https:// doi.org/10.21521/mw.6088

Kołodziej-Sobocińska M, Tokarska M, Kowalczyk R (2014a) The first report of sparganosis (Spirometra sp.) in Eurasian badger (Meles meles). Parasitol Int 63(2):397-399. https://doi.org/10.1016/j. parint.2013.12.011

Kołodziej-Sobocińska M, Zalewski A, Kowalczyk R (2014b) Sarcoptic mange vulnerability in carnivores of the Białowieża Primeval Forest, Poland: underlying determinant factors. Ecol Res 29(2): 237-244. https://doi.org/10.1007/s11284-013-1118-x

Kołodziej-Sobocińska M, Demiaszkiewicz AW, Lachowicz J, Borowik T, Kowalczyk R (2016a) Influence of management and biological factors on the parasitic invasions in the wild - spread of bloodsucking nematode Ashworthius sidemi in European bison (Bison bonasus). Int J Parasitol Parasit Wildl 5(3):286-294. https://doi. org/10.1016/j.ijppaw.2016.09.005

Kołodziej-Sobocińska M, Demiaszkiewicz AW, Pyziel AM, Marczuk B, Kowalczyk R (2016b) Does the blood-sucking nematode
Ashworthius sidemi (Trichostrongylidae) cause deterioration of blood parameters in European bison (Bison bonasus)? Eur J Wildl Res 62(6):781-785. https://doi.org/10.1007/s10344-016-1037-6

Kołodziej-Sobocińska M, Miniuk M, Ruczyńska I, Tokarska M (2016c) Sparganosis in wild boar (Sus scrofa) - implications for veterinarians, hunters, and consumers. Vet Parasitol 227:115-117. https://doi. org/10.1016/j.vetpar.2016.08.001

Kołodziej-Sobocińska M, Pyziel AM, Demiaszkiewicz AW, Borowik T, Kowalczyk R (2016d) Pattern of parasite egg shedding by European bison (Bison bonasus) in the Białowieża Primeval Forest, Poland. Mammal Res 61(3):179-186. https://doi.org/10.1007/s13364-0160270-4

Kołodziej-Sobocińska M, Brzeziński M, Niemczynowicz A, Zalewski A (2018a) High parasite infection level in non-native invasive species: it is just a matter of time. Ecography 41:1283-1294. https://doi.org/ 10.1111/ecog.03362

Kołodziej-Sobocińska M, Demiaszkiewicz AW, Pyziel AM, Kowalczyk R (2018b) Increased parasitic load in captive-released European bison (Bison bonasus) has important implications for reintroduction programs. Ecohealth 15(2):467-471. https://doi.org/10.1007/ s10393-018-1327-4

Kołodziej-Sobocińska M, Yakovlev Y, Schmidt K, Hurníková Z, Ruczyńska I, Bednarski M, Tokarska M (2018c) Update of the helminth fauna in Eurasian lynx (Lynx lynx) in Poland. Parasitol Res 117:2613-2621. https://doi.org/10.1007/s00436-018-5953-0

Kowalczyk R, Jędrzejewska B, Zalewski A, Jędrzejewski W (2008) Facilitative interactions between the Eurasian badger (Meles meles), the red fox (Vulpes vulpes), and the invasive raccoon dog (Nyctereutes procyonoides) in Białowieża Primeval Forest, Poland. Can J Zool 86(12):1389-1396. https://doi.org/10.1139/Z08-127

Kozak JM, Hudson RJ, French N, Renecker LA (1995) Winter feeding, lactation and calf growth in farmed wapiti. Ragelands 17:116-120

Krasińska M, Krasiński ZA (1995) Composition, group size, and spatial distribution of European bison bulls in Białowieża Forest. Acta Theriol 40(1):1-21

Krasińska M, Krasiński ZA, Bunevich AN (2000) Factors affecting the variability in home range size and distribution in European bison in the Polish and Belarussian parts of the Białowieża Forest. Acta Theriol 45(3):321-334

Krishnan L, Guilbert LJ, Russell AS, Wegmann TG, Mosmann TR, Belosevic M (1996) Pregnancy impairs resistance of C57BL/6 mice to Leishmania major infection and causes decreased antigenspecific IFN-gamma responses and increased production of T helper 2 cytokines. J Immunol 156(2):644-652

Krucken J, Blumke J, Maaz D, Demeler J, Ramunke S, Antolova D, Schaper R, von Samson-Himmelstjerna G (2017) Small rodents as paratenic or intermediate hosts of carnivore parasites in Berlin, Germany. PLoS ONE 12(3):e0172829. https://doi.org/10.1371/ journal.pone. 0172829

Kuijper DPJ, de Kleine C, Churski M, van Hooft P, Bubnicki J, Jedrzejewska B (2013) Landscape of fear in Europe: wolves affect spatial patterns of ungulate browsing in Białowieza Primeval Forest, Poland. Ecography 36(12):1263-1275. https://doi.org/10.1111/j. 1600-0587.2013.00266.x

Kutz SJ, Hoberg EP, Molnar PK, Dobson A, Verocai GG (2014) A walk on the tundra: host-parasite interactions in an extreme environment. Int J Parasitol Parasit Wildl 3(2):198-208. https://doi.org/10.1016/j. ijppaw.2014.01.002

Lafferty KD (2009) The ecology of climate change and infectious diseases. Ecology 90(4):888-900. https://doi.org/10.1890/08-0079.1

Lassen B, Janson M, Viltrop A, Neare K, Hutt P, Golovljova I, Tummeleht L, Jokelainen P (2016) Serological evidence of exposure to globally relevant zoonotic parasites in the Estonian population. PLoS ONE 11(10):e0164142. https://doi.org/10.1371/journal.pone. 0164142 
Laurimaa L, Süld K, Davison J, Moks E, Valdmann H, Saarma U (2016) Alien species and their zoonotic parasites in native and introduced ranges: the raccoon dog example. Vet Parasitol 219:24-33. https:// doi.org/10.1016/j.vetpar.2016.01.020

Lee K-T, Min H-K, Soh C-T (1976) Transplacental migration of Toxocara canis larvae in experimentally infected mice. J Parasitol 62(3):460-465

Lefevre T, Lebarbenchon C, Gauthier-Clerc M, Misse D, Poulin R, Thomas F (2009) The ecological significance of manipulative parasites. Trends Ecol Evol 24(1):41-48. https://doi.org/10.1016/j.tree. 2008.08.007

Lempp C, Jungwirth N, Grilo ML, Reckendorf A, Ulrich A, van Neer A, Bodewes R, Pfankuche VM, Bauer C, Osterhaus ADME, Baugärtner W (2017) Pathological findings in the red fox (Vulpes vulpes), stone marten (Martes foina) and raccoon dog (Nyctereutes procyonoides), with special emphasis on infectious and zoonotic agents in northern Germany. PLoS One 12(4):e0175469. https:// doi.org/10.1371/journal.pone.0175469

Lindenfors P, Nunn CL, Jones KE, Cunningham AA, Sechrest W, Gittleman JL (2007) Parasite species richness in carnivores: effects of host body mass, latitude, geographical range and population density. Glob Ecol Biogeogr 16(4):496-509. https://doi.org/10.1111/j. 1466-8238.2006.00301.x

Lloyd S (1983) Effect of pregnancy and lactation upon infection. Vet Immunol Immunopathol 4(1-2):153-176. https://doi.org/10.1016/ 0165-2427(83)90057-0

Loarie SR, van Aarde RJ, Pimm SL (2009) Elephant seasonal vegetation preferences across dry and wet savannas. Biol Conserv 142(12): 3099-3107. https://doi.org/10.1016/j.biocon.2009.08.021

Lozano GA (1991) Optimal foraging theory - a possible role for parasites. Oikos 60(3):391-395. https://doi.org/10.2307/3545084

Lymbery AJ, Morine M, Kanani HG, Beatty SJ, Morgan DL (2014) Coinvaders: the effects of alien parasites on native hosts. Int J Parasitol Parasit Wildl 3(2):171-177. https://doi.org/10.1016/j.ijppaw.2014. 04.002

Machnicka-Rowińska B, Rocki B, Dziemian E, Kołodziej-Sobocińska M (2002) Raccoon dog (Nyctereutes procyonoides) - the new host of Echinococcus multilocularis in Poland. Wiad Parazytol 48(1):65-68

Mackenstedt U, Jenkins D, Romig T (2015) The role of wildlife in the transmission of parasitic zoonoses in peri-urban and urban areas. Int J Parasitol Parasit Wildl 4(1):71-79. https://doi.org/10.1016/j. ijppaw.2015.01.006

Magi M, Macchioni F, Dell'omodarme M, Prati MC, Calderini P, Gabrielli S, Iori A, Cancrini G (2009) Endoparasites of red fox (Vulpes vulpes) in Central Italy. J Wildl Dis 45:881-885. https:// doi.org/10.7589/0090-3558-45.3.881

Martin LB, Scheuerlein A, Wikelski M (2003) Immune activity elevates energy expenditure of house sparrows: a link between direct and indirect costs? Proc R Soc B-Biol Sci 270(1511):153-158. https:// doi.org/10.1098/rspb.2002.2185

Martin LB, Weil ZM, Nelson RJ (2008) Seasonal changes in vertebrate immune activity: mediation by physiological trade-offs. Philos Trans R Soc B-Biol Sci 363(1490):321-339. https://doi.org/10. 1098/rstb.2007.2142

Martínek K, Kolárová L, Hapl E, Literák I, Uhrin M (2001) Echinococcus multilocularis in European wolves (Canis lupus). Parasitol Res 87(10):838-839. https://doi.org/10.1007/s004360100452

Mathews F, Moro D, Strachan R, Gelling M, Buller N (2006) Health surveillance in wildlife reintroductions. Biol Conserv 131(2):338347. https://doi.org/10.1016/j.biocon.2006.04.011

Milinski M (1984) Parasites determine a predators optimal feeding strategy. Behav Ecol Sociobiol 15(1):35-37. https://doi.org/10.1007/ bf00310212

Møller AP (2005) Parasitism and the regulation of host populations. In: Thomas F, Renaud F, Guégan J-F (eds) Parasitism and ecosystems. Oxford University Press, Oxford, pp 43-53
Moore J (1984) Altered behavioral responses in intermediate hosts - an acanthocephalan parasite strategy. Am Nat 123(4):572-577. https:// doi.org/10.1086/284224

Murray MH, Becker DJ, Hall RJ, Hernandez SM (2016) Wildlife health and supplemental feeding: a review and management recommendations. Biol Conserv 204:163-174. https://doi.org/10.1016/j.biocon. 2016.10.034

Mysterud A, Qviller L, Meisingset EL, Viljugrein H (2016) Parasite load and seasonal migration in red deer. Oecologia 180(2):401-407. https://doi.org/10.1007/s00442-015-3465-5

Nahorski WL, Knap JP, Pawłowski ZS, Krawczyk M, Polański J, Stefaniak J, Patkowski W, Szostakowska B, Pietkiewicz H, Grzeszczuk A, Felczak-Korzybska I, Gołąb E, Wnukowska N, Paul M, Kacprzak E, Sokolewicz-Bobrowska E, NiścigorskaOlsen J, Czyrznikowska A, Chomicz L, Cielecka D, Myjak P (2013) Human alveolar echinococcosis in Poland: 1990-2011. PloS Neglect Trop Dis 7(1):e1986. https://doi.org/10.1371/journal. pntd.0001986

Napoli E, Anile S, Arrabito C, Scornavacca D, Mazzamuto MV, Gaglio G, Otranto D, Giannetto S, Brianti E (2016) Survey on parasitic infections in wildcat (Felis silvestris silvestris Schreber, 1777) by scat collection. Parasitol Res 115:255-261. https://doi.org/10.1007/ s00436-015-4742-2

Oivanen L, Kapel CMO, Pozio E, La Rosa G, Mikkonen T, Sukura A (2002) Associations between Trichinella species and host species in Finland. J Parasitol 88:84-88. https://doi.org/10.2307/3285395

Oja R, Velstrom K, Moks E, Jokelainen P, Lassen B (2017) How does supplementary feeding affect endoparasite infection in wild boar? Parasitol Res 116(8):2131-2137. https://doi.org/10.1007/s00436017-5512-0

Oksanen A, Siles-Lucas M, Karamon J, Possenti A, Conraths FJ, Romig T, Wysocki P, Mannocci A, Mipatrini D, La Torre G, Boufana B, Casulli A (2016) The geographical distribution and prevalence of Echinococcus multilocularis in animals in the European Union and adjacent countries: a systematic review and meta-analysis. Parasit Vectors 9:519. https://doi.org/10.1186/s13071-016-1746-4

Oliver MK, Piertney SB, Zalewski A, Melero Y, Lambin X (2016) The compensatory potential of increased immigration following intensive American mink population control is diluted by male-biased dispersal. Biol Invasions 18(10):3047-3061. https://doi.org/10. 1007/s10530-016-1199-x

Ostfeld RS, Holt RD (2004) Are predators good for your health? Evaluating evidence for top-down regulation of zoonotic disease reservoirs. Front Ecol Environ 2(1):13-20. https://doi.org/10.2307/ 3868290

Pampiglione S, Fioravanti ML, Rivasi F (2003) Human sparganosis in Italy. Case report and review of the European cases. APMIS 111: 349-354

Pannwitz G, Meyer-Scholl A, Balicka-Ramisz A (2010) Increased prevalence of Trichinella spp., northeastern Germany. Emerg Infect Dis 16:936-942

Papadopoulos E, Komnenou A, Poutachides T, Heikkinen P, Oksanen A, Karamanlidis AA (2017) Detection of Dirofilaria immitis in a brown bear (Ursus arctos) in Greece. Helminthologia 54(3):257-261. https://doi.org/10.1515/helm-2017-0033

Peacock SJ, Bouhours J, Lewis MA, Molnar PK (2018) Macroparasite dynamics of migratory host populations. Theor Popul Biol 120:29 41. https://doi.org/10.1016/j.tpb.2017.12.005

Pedersen AB, Fenton A (2007) Emphasizing the ecology in parasite community ecology. Trends Ecol Evol 22(3):133-139. https://doi.org/ 10.1016/j.tree.2006.11.005

Pedersen AB, Jones KE, Nunn CL, Altizer S (2007) Infectious diseases and extinction risk in wild mammals. Conserv Biol 21(5):1269 1279. https://doi.org/10.1111/j.1523-1739.2007.00776.x 
Pence DB, Ueckermann E (2002) Sarcoptic mange in wildlife. Rev Sci Tech Off Int Epizoot 21(2):385-398. https://doi.org/10.20506/rst. 21.2.1335

Penezić A, Selaković S, Pavlović I, Ćirović D (2014) First findings and prevalence of adult heartworms (Dirofilaria immitis) in wild carnivores from Serbia. Parasitol Res 113(9):3281-3285. https://doi.org/ 10.1007/s00436-014-3991-9

Penezić A, Moriano R, Spasić M, Ćirović D (2018) First report of a naturally patent infection with Dirofilaria immitis in an otter (Lutra lutra). Parasitol Res 117(3):929-931. https://doi.org/10. 1007/s00436-018-5769-y

Penn D, Potts WK (1998) Chemical signals and parasite-mediated sexual selection. Trends Ecol Evol 13(10):391-396. https://doi.org/10. 1016/s0169-5347(98)01473-6

Poeppl W, Herkner H, Tobudic S, Faas A, Mooseder G, Burgmann H, Auer H (2013) Exposure to Echinococcus multilocularis, Toxocara canis, and Toxocara cati in Austria: a nationwide cross-sectional seroprevalence study. Vector-Borne Zoonotic Dis 13(11):798-803. https://doi.org/10.1089/vbz.2012.1283

Polley L (2005) Navigating parasite webs and parasite flow: emerging and re-emerging parasitic zoonoses of wildlife origin. Int J Parasitol 35(11-12):1279-1294. https://doi.org/10.1016/j.ijpara.2005.07.003

Popiołek M, Szczęsna-Staśkiewicz J, Bartoszewicz M, Okarma H, Smalec B, Zalewski A (2011) Helminth parasites of an introduced invasive carnivore species, the raccoon (Procyon lotor L.), from the Warta Mouth National Park (Poland). J Parasitol 97:357-360. https://doi.org/10.1645/GE-2525.1

Poulin R (1996) Helminth growth in vertebrate hosts: does host sex matter? Int J Parasitol 26(11):1311-1315. https://doi.org/10.1016/ s0020-7519(96)00108-7

Poulin R (2017) Invasion ecology meets parasitology: advances and challenges. Int J Parasitol Parasit Wildl 6:361-363. https://doi.org/10. 1016/j.ijppaw.2017.03.006

Poulin R, Paterson RA, Townsend CR, Tomkins DM, Kelly DW (2011) Biological invasions and the dynamics of endemic diseases in freshwater ecosystems. Freshw Biol 56:676-688

Pozio E (2000) Factors affecting the flow among domestic, synanthropic and sylvatic cycles of Trichinella. Vet Parasitol 93:241-262. https:// doi.org/10.1016/s0304-4017(00)00344-7

Prado F, Sheih A, West JD, Kerr B (2009) Coevolutionary cycling of host sociality and pathogen virulence in contact networks. J Theor Biol 261(4):561-569. https://doi.org/10.1016/j.jtbi.2009.08.022

Prenter J, MacNeil C, Dick JTA, Dunn AM (2004) Roles of parasites in animal invasions. Trends Ecol Evol 19(7):385-390. https://doi.org/ 10.1016/j.tree.2004.05.002

Price PW, Westoby M, Rice B, Atsatt PR, Fritz RS, Thompson JN, Mobley K (1986) Parasite mediation in ecological interactions. Ann Rev Ecol Systematics 17:487-505

Price PW, Westoby M, Rice B (1988) Parasite-mediated competition some predictions and tests. Am Nat 131(4):544-555. https://doi.org/ $10.1086 / 284805$

Pyziel AM, Kowalczyk R, Demiaszkiewicz AW (2011) The annual cycle of shedding Eimeria oocysts by European bison (Bison bonasus) in the Białowieża Primeval Forest, Poland. J Parasitol 97(4):737-739. https://doi.org/10.1645/Ge-2567.1

Radwan J, Demiaszkiewicz AW, Kowalczyk R, Lachowicz J, Kawałko A, Wójcik JM, Pyziel AM, Babik W (2010) An evaluation of two potential risk factors, MHC diversity and host density, for infection by an invasive nematode Ashworthius sidemi in endangered European bison (Bison bonasus). Biol Conserv 143(9):2049-2053. https://doi.org/10.1016/j.biocon.2010.05.012

Raffel TR, Hoverman JT, Halstead NT, Michel PJ, Rohr JR (2010) Parasitism in a community context: trait-mediated interactions with competition and predation. Ecology 91(7):1900-1907. https://doi. org/10.1890/09-1697.1
Reiterová K, Dziemian E, Miterpáková M, Antolová D, KołodziejSobocińska M, Machnicka B, Dubinsky P (2006) Occurrence of Echinococcus multilocularis in red foxes from the Carpathian regions of Slovakia and Poland. Acta Parasitol 51(2):107-110. https://doi.org/10.2478/s11686-006-0016-6

Rentería-Solís Z, Hamedy A, Michler FUF, Riehn K (2013) Alaria alata mesocercariae in raccoons (Procyon lotor) in Germany. Parasitol Res 112(10):3595-3600. https://doi.org/10.1007/s00436-013$3547-4$

Rentería-Solís Z, Birka S, Schmaschke R, Krol N, Obiegala A (2018a) First detection of Baylisascaris procyonis in wild raccoons (Procyon lotor) from Leipzig, Saxony, eastern Germany. Parasitol Res. https:// doi.org/10.1007/s00436-018-5988-2

Rentería-Solís Z, Kołodziej-Sobocińska M, Riehn K (2018b) Alaria spp. mesocercariae in Eurasian badger (Meles meles) and wild boar (Sus scrofa) from the Białowieża Forest, North-Eastern Poland. Parasitol Res 117(4):1297-1299. https://doi.org/10.1007/s00436-018-5819-5

Reperant LA, Hegglin D, Fischer C, Kohler L, Weber JM, Deplazes P (2007) Influence of urbanization on the epidemiology of intestinal helminths of the red fox (Vulpes vulpes) in Geneva, Switzerland. Parasitol Res 101:605-611. https://doi.org/10.1007/s00436-0070520-0

Riba L, Tena J (1999) La marmotte (Marmota marmota) en principauté d'andorre. Données démographiques et sanitaires. In: Ramousse R, Le Berre M (eds) Proceedings of the 5ème Journée d'Etude sur la Marmotte Alpine. International Marmot Network, Lyon, France, pp 27-32

Rocchigiani G, Ebani VV, Nardoni S, Bertelloni F, Bascherini A, Leoni A, Mancianti F, Poli A (2018) Molecular survey on the occurrence of arthropod-borne pathogens in wild brown hares (Lepus europaeus) from Central Italy. Inf Genet Evol 59:142-147. https:// doi.org/10.1016/j.meegid.2018.02.005

Rogers WP, Sommerville RI (1963) The infective stage of nematode parasites and its significance in parasitism. Adv Parasitol 1:109 177. https://doi.org/10.1016/s0065-308x(08)60503-5

Rohr JR, Civitello DJ, Crumrine PW, Halstead NT, Miller AD, Schotthoefer AM, Stenoien C, Johnson LB, Beasley VR (2015) Predator diversity, intraguild predation, and indirect effects drive parasite transmission. Proc Natl Acad Sci U S A 112(10):30083013. https://doi.org/10.1073/pnas.1415971112

Romeo C, Ferrari N, Lanfranchi P, Saino N, Santicchia F, Martinoli A, Wauters LA (2015) Biodiversity threats from outside to inside: effect of alien grey squirrel (Sciurus carolinensis) on helminth community of native red squirrel (Sciurus vulgaris). Parasitol Res 114: 2621-2628. https://doi.org/10.1007/s00436-015-4466-3

Rook GAW (2007) The hygiene hypothesis and the increasing prevalence of chronic inflammatory disorders. Trans R Soc Trop Med Hyg 101(11):1072-1074. https://doi.org/10.1016/i.trstmh.2007.05.014

Sánchez CA, Becker DJ, Teitelbaum CS, Barriga P, Brown LM, Majewska AA, Hall RJ, Altizer S (2018) On the relationship between body condition and parasite infection in wildlife: a review and meta-analysis. Ecol Lett 21:1869-1884. https://doi.org/10.1111/ele. 13160

Sarabian C, Curtis V, McMullan R (2018) Evolution of pathogen and parasite avoidance behaviours. Philos Trans R Soc B-Biol Sci 373(1751):20170256. https://doi.org/10.1098/rstb.2017.0256

Schmid-Hempel P (2011) Evolutionary parasitology: the integrated study of infections, immunology, ecology, and genetics. Oxford University Press, Oxford

Schmidt K, Kuijper DPJ (2015) A "death trap" in the landscape of fear. Mammal Res 60(4):275-284. https://doi.org/10.1007/s13364-0150229-x

Schmidt K, Jędrzejewski W, Okarma H (1997) Spatial organization and social relations in the Eurasian lynx population in Białowieża Primeval Forest, Poland. Acta Theriol 42(3):289-312 
Schulte-Hostedde AI, Elsasser SC (2011) Spleen mass, body condition, and parasite load in male American mink (Neovison vison). J Mammal 92(1):221-226. https://doi.org/10.1644/10-mamm-a-020. 1

Schulte-Hostedde AI, Zinner B, Millar JS, Hickling GJ (2005) Restitution of mass-size residuals: validating body condition indices. Ecology 86(1):155-163. https://doi.org/10.1890/04-0232

Schweiger A, Ammann RW, Candinas D, Clavien PA, Eckert J, Gottstein B, Halkic N, Muellhaupt B, Prinz BM, Reichen J, Tarr PE, Torgerson PR, Deplazes P (2007) Human alveolar echinococcosis after fox population increase, Switzerland. Emerg Infect Dis 13(6): 878-882. https://doi.org/10.3201/eid1306.061074

Scott ME (1988) The impact of infection and disease on animal populations: implications for conservation biology. Conserv Biol 2(1):4056. https://doi.org/10.1111/j.1523-1739.1988.tb00334.x

Serrano-Moliner M, Morales-Suarez-Varela M, Valero MA (2018) Epidemiology and management of foodborne nematodiasis in the European Union, systematic review 2000-2016. Pathog Glob Health. https://doi.org/10.1080/20477724.2018.1487663

Sherrard-Smith E, Chadwick EA, Cable J (2015) The impact of introduced hosts on parasite transmission: opisthorchiid infections in American mink (Neovison vison). Biol Invasions 17(1):115-122. https://doi.org/10.1007/s10530-014-0709-y

Shimalov VV (2002) Helminth fauna of the striped field mouse (Apodemus agrarius Pallas, 1778) in ecosystems of Belorussian Polesie transformed as a result of reclamation. Parasitol Res 88(11):1009-1010. https://doi.org/10.1007/s004360100416

Shimalov VV (2017) Helminth parasites of the Eurasian water shrew (Neomys fodiens pennant, 1771) in South-West Belarus. J Parasit Dis 41(2):602-604. https://doi.org/10.1007/s12639-016-0847-5

Shimalov VV, Shimalov VT (2000) Helminth fauna of the wolf (Canis lupus Linnaeus, 1758) in Belorussian Polesie. Parasitol Res 86(2): 163-164

Shimalov VV, Shimalov VT (2001a) Helminth fauna of the American mink (Mustela vison Schreber, 1777) in Belorussian Polesie. Parasitol Res 87(10):886-887. https://doi.org/10.1007/ s004360100461

Shimalov VV, Shimalov VT (2001b) Helminth fauna of the stoat (Mustela erminea Linneus, 1758) and the weasel (M. nivalis Linnaeus, 1758) in Belarusian Polesie. Parasitol Res 87(8):680681. https://doi.org/10.1007/s004360000373

Shimalov VV, Shimalov VT (2001c) Helminth fauna of the European mole (Talpa earopaea Linnaeus, 1758) in Belorussian Polesie. Parasitol Res 87(9):790-791. https://doi.org/10.1007/ s004360100438

Shimalov VV, Shimalov VT (2002a) Helminth fauna of the raccoon dog (Nyctereutes procyonoides Gray, 1834) in Belorussian Polesie. Parasitol Res 88:944-945. https://doi.org/10.1007/s00436-0010582-3

Shimalov VV, Shimalov VT (2002b) Helminth fauna of the European polecat (Mustela putorius Linnaeus, 1758) in Belorussian Polesie. Parasitol Res 88(3):259-260. https://doi.org/10.1007/s00436-0010521-3

Shimalov VV, Shimalov VT (2003) Helminth fauna of the red fox (Vulpes vulpes Linnaeus, 1758) in southern Belarus. Parasitol Res 89(1):7778. https://doi.org/10.1007/s00436-002-0701-9

Shimalov VV, Shimalov VT, Shimalov AV (2000) Helminth fauna of otter (Lutra lutra Linneaeus, 1758) in Belorussian Polesie. Parasitol Res 86(6):528. https://doi.org/10.1007/s004360050708

Sinclair ARE, Mduma SAR, Arcese P (2000) What determines phenology and synchrony of ungulate breeding in Serengeti? Ecology 81(8): 2100-2111

Smith GC, Gangadharan B, Taylor Z, Laurenson MK, Bradshaw H, Hide G, Hughes JM, Dinkel A, Romig T, Craig PS (2003) Prevalence of zoonotic important parasites in the red fox (Vulpes vulpes) in Great
Britain. Vet Parasitol 118:133-142. https://doi.org/10.1016/j.vetpar. 2003.09.017

Smith MJ, Telfer S, Kallio ER, Burthe S, Cook AR, Lambin X, Begon M (2009) Host-pathogen time series data in wildlife support a transmission function between density and frequency dependence. Proc Natl Acad Sci U S A 106(19):7905-7909. https://doi.org/10.1073/ pnas.0809145106

Solomon NU, James IM, Alphonsus NO, Nkiruka RU (2015) A review of host-parasite relationships. Annu Res Rev Biol 5:372-385. https:// doi.org/10.9734/ARRB/2015/10263

Sorensen A, van Beest FM, Brook RK (2014) Impacts of wildlife baiting and supplemental feeding on infectious disease transmission risk: a synthesis of knowledge. Prev Vet Med 113(4):356-363. https://doi. org/10.1016/j.prevetmed.2013.11.010

Stien A, Irvine RJ, Ropstad E, Halvorsen O, Langvatn R, Albon SD (2002) The impact of gastrointestinal nematodes on wild reindeer: experimental and cross-sectional studies. J Anim Ecol 71:937-945

Stricker KB, Harmon PF, Goss EM, Clay K, Flory SL (2016) Emergence and accumulation of novel pathogens suppress an invasive species. Ecol Lett 19(4):469-477. https://doi.org/10.1111/ele.12583

Stringer AP, Linklater WL (2015) Host density drives macroparasite abundance across populations of a critically endangered megaherbivore. Oecologia 179(1):201-207. https://doi.org/10. 1007/s00442-015-3319-1

Stuart P, Golden O, Zintl A, de Waal T, Mulcahy G, McCarthy E, Lawton C (2013) A coprological survey of parasites of wild carnivores in Ireland. Parasitol Res 112:3587-3593

Studer A, Thieltges DW, Poulin R (2010) Parasites and global warming: net effects of temperature on an intertidal host-parasite system. Mar Ecol Prog Ser 415:11-22. https://doi.org/10.3354/meps08742

Sugiura N, Doi K, Kato T, Morita T, Hayama S (2018) Epizootic of sarcoptic mange in raccoon dogs (Nyctereutes procyonoides) in relation to population density. J Vet Med Sci 80(3):544-548. https:// doi.org/10.1292/jvms.17-0092

Suld K, Valdmann H, Laurimaa L, Soe E, Davison J, Saarma U (2014) An invasive vector of zoonotic disease sustained by anthropogenic resources: the raccoon dog in northern Europe. PLoS One 9(5): e96358. https://doi.org/10.1371/journal.pone.0096358

Sutor A, Schwarz S, Conraths FJ (2014) The biological potential of the raccoon dog (Nyctereutes procyonoides, Gray 1834) as an invasive species in Europe - new risks for disease spread? Acta Theriol 59(1): 49-59. https://doi.org/10.1007/s13364-013-0138-9

Szczęsna J, Popiołek M, Schmidt K, Kowalczyk R (2008) Coprological study on helminth fauna in Eurasian lynx (Lynx lynx) from the Białowieża Primeval Forest in eastern Poland. J Parasitol 94(4): 981-984. https://doi.org/10.1645/Ge-1440.1

Tăbăran F, Sándor AD, Marinov M, Cătoi C, Mihalca AD (2013) Alaria alata infection in European mink. Emerg Inf Dis 19(9):1547-1549. https://doi.org/10.3201/eid1909.130081

Taraschewski H (2006) Hosts and parasites as aliens. J Helminthol 80:99_ 128. https://doi.org/10.1079/JOH2006364

Teitelbaum CS, Huang S, Hall RJ, Altizer S (2018) Migratory behaviour predicts greater parasite diversity in ungulates. Proc R Soc B Biol Sci 285(1875):20180089. https://doi.org/10.1098/rspb.2018.0089

Telfer S, Birtles R, Bennett M, Lambin X, Paterson S, Begon M (2008) Parasite interactions in natural populations: insights from longitudinal data. Parasitology 135(7):767-781. https://doi.org/10.1017/ s0031182008000395

Telfer S, Lambin X, Birtles R, Beldomenico P, Burthe S, Paterson S, Begon M (2010) Species interactions in a parasite community drive infection risk in a wildlife population. Science 330(6001):243-246. https://doi.org/10.1126/science.1190333

Theis JH, Schwab RG (1992) Seasonal prevalence of Taenia taeniaeformis - relationship to age, sex, reproduction and abundance of an intermediate host (Peromyscus maniculatus). J Wildl Dis 28: $42-50$ 
Thomas F, Renaud F, Meeüs T, Cézilly F (1995) Parasites, age and the Hamilton-Zuk hypothesis: inferential fallacy? OIKOS 74:305-309

Thompson RCA (2013) Parasite zoonoses and wildlife: one health, spillover and human activity. Int J Parasitol 43(12-13):1079-1088. https://doi.org/10.1016/j.ijpara.2013.06.007

Thompson RCA, Lymbery AJ, Smith A (2010) Parasites, emerging disease and wildlife conservation. Int J Parasitol 40(10):1163-1170. https://doi.org/10.1016/j.ijpara.2010.04.009

Tompkins DM, Dunn AM, Smith MJ, Telfer S (2011) Wildlife diseases: from individuals to ecosystems. J Anim Ecol 80(1):19-38. https:// doi.org/10.1111/j.1365-2656.2010.01742.x

Torchin ME, Mitchell CE (2004) Parasites, pathogens, and invasions by plants and animals. Front Ecol Environ 2(4):183-190. https:// doi.org/10.1890/1540-9295(2004)002[0183:ppaibp]2.0.co;2

Torchin ME, Lafferty KD, Dobson AP, McKenzie VJ, Kuris AM (2003) Introduced species and their missing parasites. Nature 421(6923): 628-630. https://doi.org/10.1038/nature01346

Torres J, Miquel J, Casanova JC, Ribas A, Feliu C, Morand S (2006) Endoparasite species richness of Iberian carnivores: influences of host density and range distribution. Biodivers Conserv 15(14): 4619-4632. https://doi.org/10.1007/s10531-005-5824-8

Treboganova N (2010) Behavior of the bison and helminthoses. Eur Bison Cnserv Newslett 3:125-134

Turgeon G, Kutz SJ, Lejeune M, St-Laurent M-H, Pelletier F (2018) Parasite prevalence, infection intensity and richness in an endangered population, the Atlantic-Gaspésie caribou. Int J Parasitol Parasit Wildl 7(1):90-94. https://doi.org/10.1016/j.ijppaw.2018.02. 001

Turner WC, Getz WM (2010) Seasonal and demographic factors influencing gastrointestinal parasitism in ungulates of Etosha National Park. J Wildl Dis 46(4):1108-1119. https://doi.org/10. 7589/0090-3558-46.4.1108

Vadlejch J, Kyriánová IA, Rylková K, Zikmund M, Langrová I (2016) Health risks associated with wild animal translocation: a case of the European bison and an alien parasite. Biol Invasions 19(4):11211125. https://doi.org/10.1007/s10530-016-1306-z

Vergles Rataj A, Posedi J, Zele D, Vengušt G (2013) Intestinal parasites of the red fox (Vulpes vulpes) in Slovenia. Acta Vet Hung 61:454-462. https://doi.org/10.1556/AVet.2013.029

Vichova B, Majlathova V, Novakova M, Majlath I, Curlik J, Bona M, Komjati-Nagyova M, Petko B (2011) PCR detection of re-emerging tick-borne pathogen, Anaplasma phagocytophilum, in deer ked (Lipoptena cervi) a blood-sucking ectoparasite of cervids. Biologia 66(6):1082-1086. https://doi.org/10.2478/s11756-011-0123-1

Viggers KL, Lindenmayer DB, Spratt DM (1993) The importance of diseases in reintroduction programs. Wildl Res 20(5):687-698. https://doi.org/10.1071/wr9930687
Viney ME, Graham AL (2013) Chapter five - patterns and processes in parasite co-infection. Adv Parasitol Rollinson D, Academic Press 82:321-369

Wakelin D (1978) Genetic control of susceptibility and resistance to parasitic infection. In: Lumsden WHR, RM BJR (eds) Adv Parasitol. vol 16. Academic Press, Cambridge, pp 219-308

Walker SM, Demiaszkiewicz AW, Kozak M, Wędrychowicz H, Teofanova D, Prodohl P, Brennan G, Fairweather I, Hoey EM, Trudgett A (2013) Mitochondrial DNA haplotype analysis of liver fluke in bison from Białowieża Primeval Forest indicates domestic cattle as the likely source of infection. Vet Parasitol 191(1-2):161164. https://doi.org/10.1016/j.vetpar.2012.08.002

Wang HH, Grant WE, Teel PD, Hamer SA (2016) Tick-borne infectious agents in nature: simulated effects of changes in host density on spatial-temporal prevalence of infected ticks. Ecol Model 323:7786. https://doi.org/10.1016/j.ecolmodel.2015.11.021

Watve MG, Sukumar R (1995) Parasite abundance and diversity in mammals - correlates with host ecology. Proc Natl Acad Sci U S A 92(19):8945-8949. https://doi.org/10.1073/pnas.92.19.8945

Weinstein SB, Buck JC, Young HS (2018a) A landscape of disgust. Science 359(6381):1213-1214. https://doi.org/10.1126/science. aas 8694

Weinstein SB, Moura CW, Mendez JF, Lafferty KD (2018b) Fear of feces? Tradeoffs between disease risk and foraging drive animal activity around raccoon latrines. OIKOS 127(7):927-934. https:// doi.org/10.1111/oik.04866

Wilder SM, Raubenheimer D, Simpson SJ (2016) Moving beyond body condition indices as an estimate of fitness in ecological and evolutionary studies. Funct Ecol 30(1):108-115. https://doi.org/10.1111/ $1365-2435.12460$

Winternitz JC, Yabsley MJ, Altizer SM (2012) Parasite infection and host dynamics in a naturally fluctuating rodent population. Can J Zool 90(9):1149-1160. https://doi.org/10.1139/z2012-083

Woolhouse MEJ (1998) Patterns in parasite epidemiology: the peak shift. Parasitol Today 14(10):428-434. https://doi.org/10.1016/S01694758(98)01318-0

Zalewski A, Bartoszewicz M (2012) Phenotypic variation of an alien species in a new environment: the body size and diet of American mink over time and at local and continental scales. Biol J Linnean Soc 105(3):681-693. https://doi.org/10.31111/j.1095-8312.2011. 01811.x

Zuk M, McKean KA (1996) Sex differences in parasite infections: patterns and processes. Int J Parasitol 26(10):1009-1023. https://doi. org/10.1016/S0020-7519(96)80001-4 